This item was submitted to Loughborough's Research Repository by the author.

Items in Figshare are protected by copyright, with all rights reserved, unless otherwise indicated.

\title{
Pharmaceutical particles design by membrane emulsification: preparation methods and applications in drug delivery
}

PLEASE CITE THE PUBLISHED VERSION

http://dx.doi.org/10.2174/1381612823666161117160940

\section{PUBLISHER}

(c) Bentham Science Publishers

\section{VERSION}

AM (Accepted Manuscript)

\section{PUBLISHER STATEMENT}

This work is made available according to the conditions of the Creative Commons Attribution-NonCommercialNoDerivatives 4.0 International (CC BY-NC-ND 4.0) licence. Full details of this licence are available at: https://creativecommons.org/licenses/by-nc-nd/4.0/

\section{LICENCE}

CC BY-NC-ND 4.0

\section{REPOSITORY RECORD}

Piacentini, Emma, Marijana M. Dragosavac, and L. Giorno. 2017. "Pharmaceutical Particles Design by Membrane Emulsification: Preparation Methods and Applications in Drug Delivery". figshare. https://hdl.handle.net/2134/25455. 
Pharmaceutical Particles Design by Membrane Emulsification: preparation methods and applications in drug delivery

\section{Emma Piacentini $^{1 *}$, Marijana Dragosavac ${ }^{2}$ Lidietta Giorno $^{1}$}

${ }^{1}$ Institute on Membrane Technology, National Research Council, ITM-CNR, Via P. Bucci 17/C at University of Calabria, 87036 Rende (CS), Italy

${ }^{2}$ Department of Chemical Engineering, Loughborough University, LE11 3TU, UK

*Correspondence: e-mail: e.piacentini@itm.cnr.it; Tel.: +39 0984492051 


\begin{abstract}
Nowadays, the rational design of particles is an important issue in the development of pharmaceutical medicaments. Advances in manufacturing methods are required to design new pharmaceutical particles with target properties in terms of particle size, particle size distribution, structure and functional activity. Membrane emulsification is emerging as a promising tool for the production of emulsions and solidified particles with tailored properties in many fields.

In this review, the current use of membrane emulsification in the production of pharmaceutical particles is highlighted. Membrane emulsification devices designed for small-scale testing as well as membrane-based methods suitable for largescale production are discussed. A special emphasis is put on the important factors that contribute to the encapsulation efficiency and drug loading. The most recent studies about the utilization of the membrane emulsification for preparing particles as drug delivery systems for anticancer, proteins/peptide, lipophilic and hydrophilic bioactive drugs are reviewed.
\end{abstract}

Keywords: Membrane emulsification, emulsions, particles, drug delivery, encapsulation efficiency, stimulus responsive, administration route, pharmaceutical field. 


\section{INTRODUCTION}

During the last decade, membrane emulsification has emerged as one of the most interesting technologies in pharmaceutical particle design [1 E. Piacentini, 2014]. In the membrane emulsification process, monodisperse droplets are generated by dispersing one liquid (dispersed phase) into a second, immiscible liquid (continuous phase) through the pores of a membrane (Figure $1 \mathrm{~A}$ ). The droplet size and droplet size distribution are mainly determined by the membrane properties (pore size, pore size distribution, membrane wettability). The optimization of the operating conditions (dispersed phase flux and shear stress) as well as of composition of the phases (density of phases and viscosity, emulsifier type and concentration) allows the production of uniform, reproducible and size-controlled droplets [2,3 Joscelyne, 2000; Charcosset, 2004].
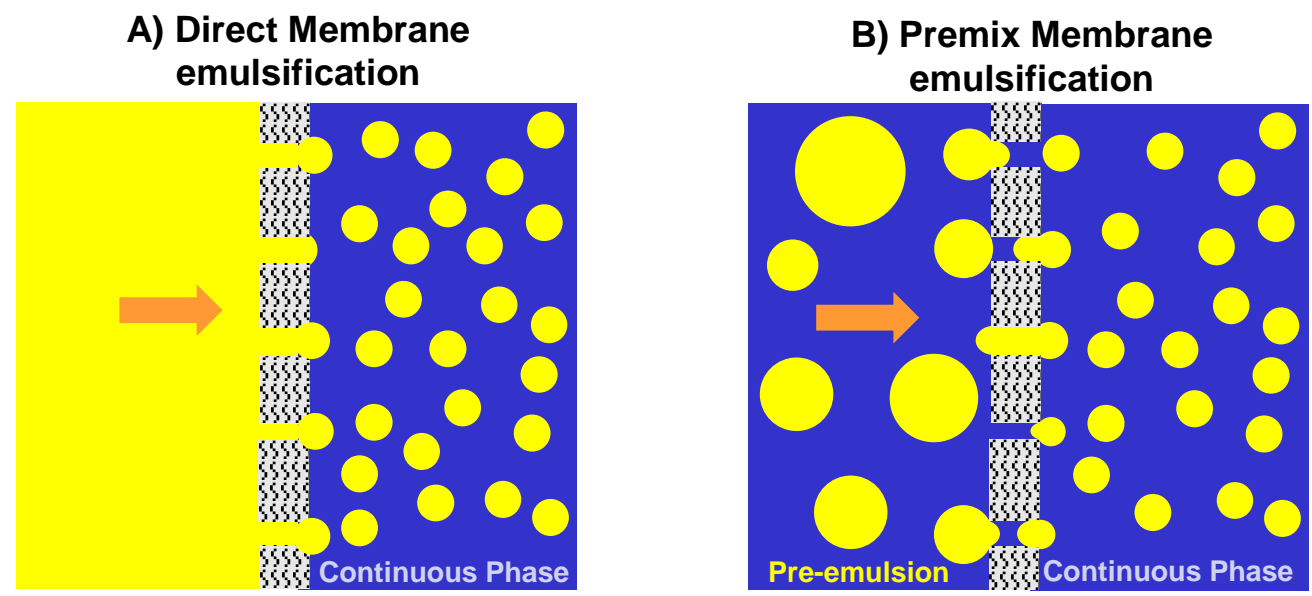

Figure 1. Membrane emulsification by A) direct and B) premix method.

In the physical sciences, a particle represents a small localized object to which can be ascribed several physical properties such as volume or mass. Particles may be solid, but they also may be liquid droplets dispersed in another immiscible liquid or air. There is a great demand from pharmaceutical industry to improve the production methods of both organic and inorganic uniform spherical particles. An emulsion is a dispersion of one liquid in another where the liquids are not miscible, or are slightly soluble, and they play a valuable role in the production of the particle. Emulsion droplets are already particles but, even more, the droplets after production may be converted into solid particles by applying an additional physical (fluidized bed coating, spray or freeze-drying, evaporation/solvent diffusion) or chemical (reacting, coacervation and interfacial polymerization) treatments [4 Dragosavac M.M 2011]. The fabrication of uniform size micro/nano-particles with well-defined properties is an essential requirement for the application in pharmaceutical field. Particles with heterogeneous size distribution are difficult to reproduce and control accurately during manufacturing and may cause an unpredictable and unreproducible release profiles with poor therapeutic effects [5, 6Wu, J., 2015; Liu, W., 2010]. Particle size plays an important role in biodistribution, targeting, uptake mechanisms, degradation and clearance. The choice of the emulsification process is a key issue in the particle production as it influences directly the final size, and size distribution, of the solid particles. Furthermore, particles size and size distribution are also directly influencing the rate of drug release which usually is the most important parameter in pharmaceutical industry. Some important challenges are required for the advancement of technologies in engineering particles with improved functional and structured properties:

i) Maintaining the performance of a good emulsification step when the process is transferred from the laboratory scale to a larger throughput scale [7 Huang et al. 2008], and

ii) Achieving a precise control of particle size and size distribution in the emulsification step while maintaining the incorporation of biomolecules without affecting their activity; the distribution in the body; the interaction with living cells as well as the drug release kinetics of the solid particles are greatly influenced by their size and uniformity [8 Benita 2006].

There are many conventional ways for preparing emulsions. In such devices, a premix emulsion is necessary, which is produced by gentle mixing, followed by homogenization which will lead to further reduction of the droplet size. In general, homogenization is an intense process: it introduces a large amount of energy into the premix emulsion to break up the droplets into smaller ones. In high-pressure systems, premix is pushed through a small valve at high pressure. Due to the high shear and extension rates in the valve, large droplets break up into smaller. In stirring vessels the droplets break up is due to the paddle stirring. The average input per unit volume is quite low and they are suitable for production of coarse emulsions, and mainly used as batch systems. In Colloidal mills, premix is pushed through the gap between a cylindrical or conical stator and rotor. Due to the shear and extension exerted by the rotor, large droplets break up into smaller ones. A laboratory homogeniser uses a very similar principle to this. In Toothed disk dispersing machines, premix is pushed through the gap between several pairs of concentrically arranged disks of various designs, one of which rotates 
due to shear and large droplets break up. In Ultrasound systems, premix is placed in a vessel with an ultra sound device. Due to the intense turbulence caused by the ultrasound waves, the droplets break up into smaller ones.

Conventional homogenizers, as mentioned above, are very convenient for production of small size droplets below $10 \mu \mathrm{m}$ [9 Karbshtein and Shubert 1995]. For production of larger droplets low shear needs to be applied, but conventional homogenisation in that case produces droplets with a wide size distribution. Such a product is often unstable and has unsatisfactory properties [4 Dragosavac M.M. 2011].

Membrane emulsification demonstrated a remarkable capability in tuning droplet size and size distribution of particles. Process flexibility led to its application in a variety of solid and advanced particles formulations for drug protection or controlled release. In addition, high encapsulation and loading efficiencies of an active pharmaceutical ingredient as well as the maintenance of the bioactivity of protein/peptide drugs can be achieved due to mild fluid-dynamic conditions.

Another challenge facing particles as drug delivery systems is the large-scale production of micro-nanostructured materials in terms of scaling up laboratory or pilot technologies for consistent and reproducible production and commercialization. The membrane emulsification process is attractive for the production of particles with homogeneous size distribution at large scale by increasing membrane area. Principles, controlling parameters and applications of membrane emulsification are reviewed in previous works [1-3, 5, 10-22] [1-12; Wang, 2015, Wu, 2015, Ma, 214, Vladisavljević G. T., 2015, Piacentini 2014]. As demonstrated by a patent analysis, the major area of application of membrane emulsification is in the medical field [1 Piacentini 2014]. The use of particles prepared by membrane emulsification in the medical field has been recently reviewed [5, 6, 21, 22 Wang, 2015, Wu, 2015, Ma, 214, 9]. The recognized benefits of membrane emulsification in pharmaceutical particle production is demonstrated by the increasing number of paper published in this field in the recent years (Figure 2).

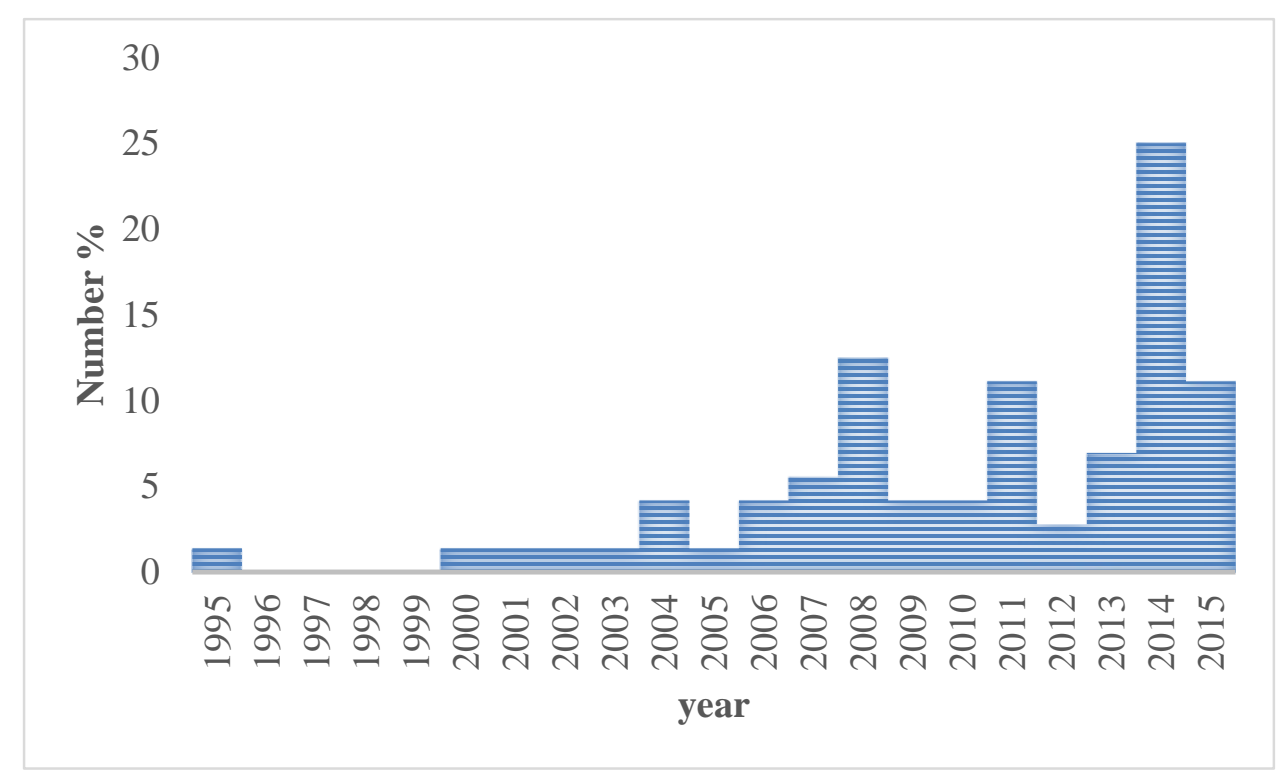

Figure 2. Publications related to pharmaceutical particles production by membrane emulsification

In this review, the power of membrane emulsification to assist the fabrication of pharmaceutical particles with tuned size, size distribution, structure, and surface properties is highlighted. In particular, this article focuses on the advances of pharmaceutical particles prepared by membrane emulsification, including devices for small and large scale application. Special emphasis has been put on the main factors to be considered for pharmaceutical particles design such as particle structure, administration route, targeting properties, drug loading and encapsulation efficiency. The most recent studies about the utilization of the membrane emulsification technique for preparing particles as drug delivery systems for anticancer, proteins/peptide, lipophilic and hydrophilic bioactive drugs are described.

FABRICATION of PHARMACEUTICAL PARTICLES BY MEMBRANE EMULSIFICATION The formulation, development and manufacture of pharmaceutical products based on particles ranges from the start of formulation optimization to final drug marketing. The membrane emulsification process provides suitable solutions for pharmaceutical particles generation at different levels:

i) Bench and lab scale testing of formulation can be performed to produce particles and emulsions with tuned structure and functional properties. 

data for process scale-up.

iii) Continuous manufacturing process can be developed by connecting in series the membrane emulsification plant with a reactor to achieve simultaneous drop generation and chemical/physicochemical reaction in the produced emulsion.

Membrane emulsification devices designed for small-scale testing are commercially available to establish the effectiveness of the membrane-based method in association with the desired formulation (Figure 3).

\section{BENCH AND LAB-SCALE MEMBRANE EMULSIFICATION DEVICES}

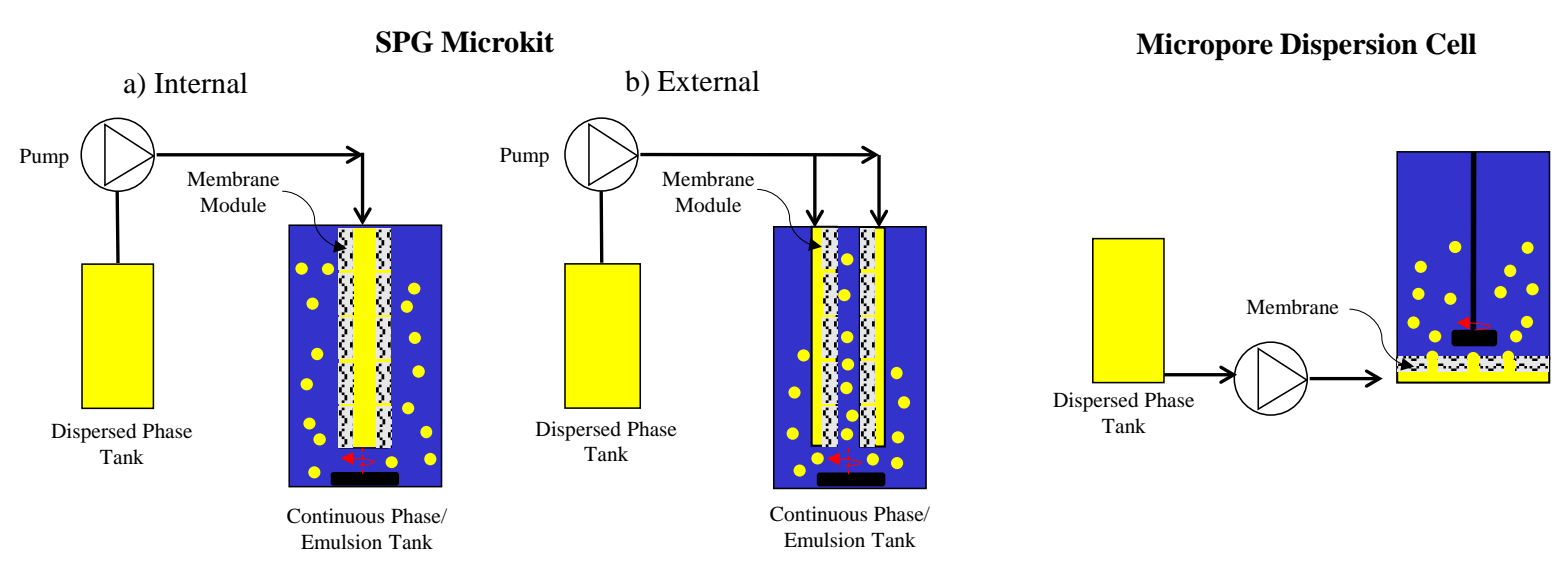

Figure 3. Membrane emulsification for droplets production at bench/lab-scale

SPG Technology Co., Ltd (Japan) developed membrane emulsification microkits that require only 8-50 $\mathrm{mL}$ of the continuous phase per single batch, which is useful for expensive clinical preparations as well as for preliminary tests for formulation optimization. In the internal-pressure type system, the inside of tube-shaped membrane is filled with the dispersed phase liquid and, the outside, with the continuous phase liquid [23 J. Lee, 2010]. The pressure is given to the inside of the membrane by use of nitrogen gas and the continuous phase is stirred by using a rotator. In the externalpressure type system, the outside of a tube-shape is filled with the dispersed phase liquid, and the inside, with the continuous phase liquid [24 L. Chu, 2003]. The pressure is given from outside to inside of SPG membrane by using nitrogen gas and the continuous phase is stirred by using a rotator. A simplified experimental set-up, suitable for bench and lab scale tests, can be used in the case of static membrane emulsification. In this method, the formation of emulsion droplets occurs in the absence of surface shear [25 Kukizaki M (2009)]. Micropore Technologies (UK) developed the Dispersion Cell in which the dispersed phase is pumped through a circular disc membrane while a gentle shear is applied by using a paddle blade stirrer, positioned above the membrane [26 M.T. Stillwell, 2007].

Many strategies have been introduced in membrane-based emulsification to meet the demanding requirements for the production of emulsions and particles with high productivity without losing the good control on particle size and particle size distribution and operating at low shear and in gentle conditions (Figure 4). They differ on the way in which the surface shear (that results in droplet detachment from the pore openings) is generated: i) by moving the continuous phase in cross-flow or pulsed mode or ii) by moving the membranes by rotation, vibration or oscillation. The dispersed phase is injected through the membrane pores by using a pump or nitrogen gas. Membrane emulsification equipment suitable for large scale production and based on the use of moving and static membranes are commercialized by SPG Technology Co., Ltd (Japan) and Micropore Technologies (UK).

In cross-flow membrane emulsification, the shear stress is generated by the recirculation of the continuous phase tangentially to the membrane surface [27 Peng and Fellow, 1998]. The method is suitable for large-scale production and continuous or semi-continuous operation. However, droplet break-up can occur over time when concentrated emulsions are produced due to the high cross-flow velocities used to obtain narrow droplet size distribution at high dispersed phase flux, or over long time of operation.

In pulsed flow membrane emulsification, a periodic flow pulsation is generated in the continuous phase without recirculation. The pulsed flow in the continuous phase is generated by a frequency generator ([28] Holdich et al. 2013) or by inverting the flow direction back-and-forward within the membrane lumen (Piacentini et al. 2014)[29]. The method is advantageous for the production of emulsions with a high dispersed to continuous phase ratio and it is suitable for largescale production in continuous or semi-continuous mode.

In an alternative, the shear stress on the membrane surface can be generated by moving the membranes by rotation, vibration or oscillation. In rotating membrane emulsification, the dispersed phase is introduced into the center of a rotating 
tubular porous membrane, and droplets are detached at the membrane wall in the radial direction into the stationary continuous phase [20] (Vladisavljević \& Williams 2006). However, the use for large scale production is limited due to the complicated and more expensive design and higher power consumption compared to alternative designs. In vibrating membrane emulsification, the membrane oscillates perpendicularly with respect to the dispersed phase injection direction [30] (Holdich et al. 2010). The frequency and amplitude of the axial oscillation of the membrane is generated by an electrically driven vertical oscillator and can be controlled separately. The two methods are particularly advantageous for the production of relatively coarse emulsions and fragile structured products in which the droplets and/or particles are subject to breakage during the pump recirculation. In azimuthally oscillating membrane emulsification, a tubular membrane is periodically rotated back-and-forward in a slowly cross flowing continuous phase [31] (Silva et al. 2015). The method operates in a continuous mode and it is suitable for large-scale production providing high production rates, facilitating easy process automation and reduced operation time.

\section{LARGE SCALE MEMBRANE EMULSIFICATION PLANTS}

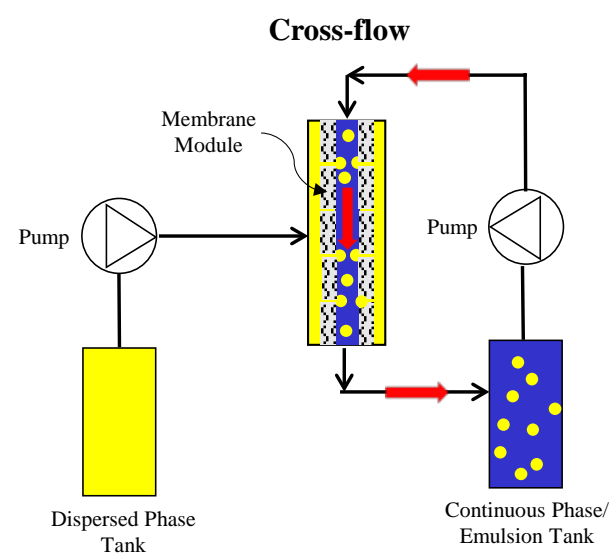

Rotating Membrane

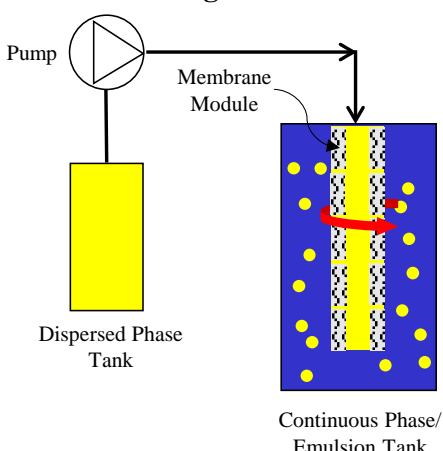

Azimuthally oscillating membrane

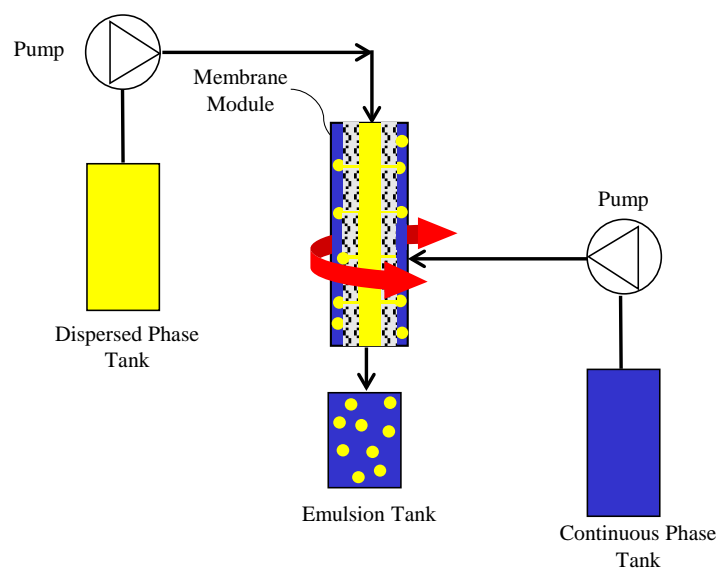

Pulsed-flow
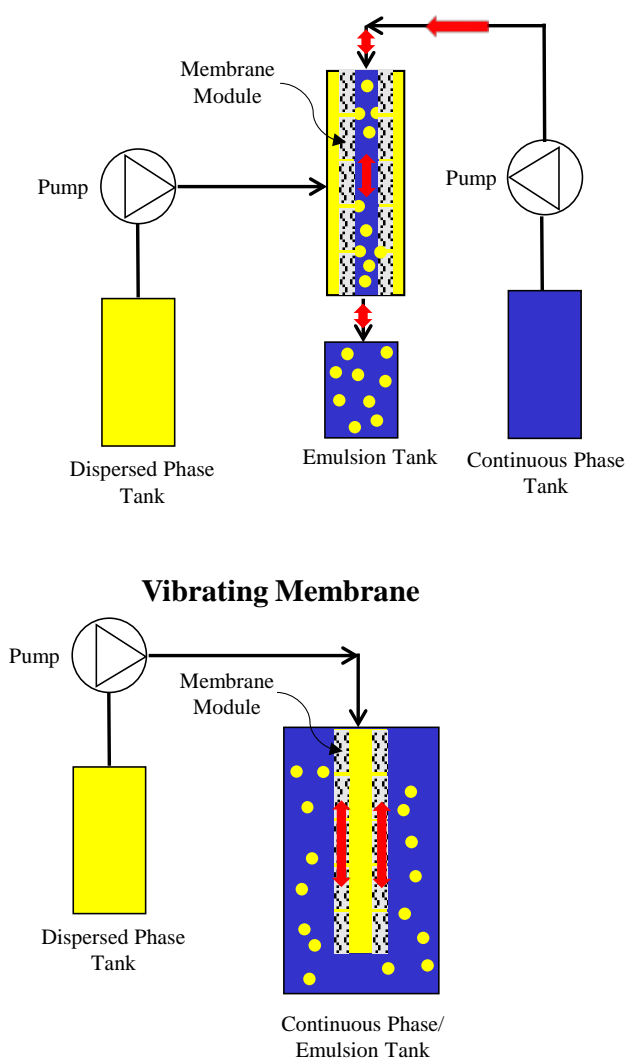

Figure 4. Membrane emulsification for droplets production at large-scale 
For preparing small droplets with high productivity, another membrane emulsification technique, premix membrane emulsification, has been developed [32 Suzuki 1996]. In premix membrane emulsification, a coarsely emulsified mixture of two immiscible liquids (pre-emulsion) is passed through a microporous membrane (Figure $1 \mathrm{~B}$ ). The advantages of this method over direct membrane emulsification (Figure $1 \mathrm{~A}$ ) are that smaller droplet sizes and higher productivity can be achieved for the given pore size but at the expense of lower degree of monodispersity. The method is suitable for large scale production in continuous or semi-continuous mode however the emulsion has repeatedly to be passed through the same membrane in order to achieve additional droplet size reduction and improve droplet size uniformity. Premix membrane emulsification equipment has been developed by SPG Technology Co., Ltd (Japan) and National Engineering Research Centre for Biotechnology (Beijing) and Zhongke Senhui Microsphere Technology (Suzhou, China) Co. Ltd. For pharmaceutical particles, scale-up without failure is a key issue. Automatic control can avoid failure of large-scale production, especially for the direct membrane emulsification process. An automatic SPG membrane emulsification equipment for large-scale production and suitable for both direct and premix process equipped with temperature and parameters of production process control systems is commercialized by Zhongke Senhui Company.

Pharmaceutical particles with target size, uniform size distribution and a reasonable productivity for specific industrial requests, can be obtained by tuning operational, formulation and membrane parameters. General rules governing particle production by membrane emulsification to achieve control over the particle size, uniform particle size distribution and high productivity are summarized in Table 1.

Table 1. General rules to tune particle size, particle size distribution and process productivity by membrane emulsification process.

\begin{tabular}{|l|l|l|}
\hline \multicolumn{1}{|c|}{ Tuned Particle size } & Uniform particle size distribution & \multicolumn{1}{|c|}{ High productivity } \\
\hline $\begin{array}{l}\text { Membranes with pore size lower than } \\
\text { the target particle size (Dp }=\mathrm{x} \text { Dd, } \\
0.1<\mathrm{x}<0.5 \text { (Katoh et al. 1996) [33] }\end{array}$ & $\begin{array}{l}\text { Membranes with uniform pore size } \\
\text { distribution }\end{array}$ & $\begin{array}{l}\text { Membranes with larger pore size and } \\
\text { higher porosity }\end{array}$ \\
\hline $\begin{array}{l}\text { Membranes un-wetted by the } \\
\text { dispersed phase. Hydrophilic and } \\
\text { hydrophobic membrane are used for } \\
\text { production of O/W and W/O } \\
\text { emulsion, respectively (Piacentini et } \\
\text { al. 2014). [34] }\end{array}$ & $\begin{array}{l}\text { Membranes with low porosity and } \\
\text { avoid droplets coalesce at the pore } \\
\text { level [Kobayashi et al. 2002] [37] }\end{array}$ & $\begin{array}{l}\text { Asymmetrically wetted membranes } \\
\text { (membranes pore wall with good } \\
\text { wettability to the dispersed phase } \\
\text { allows quick permeation of the } \\
\text { phase in the pores (Piacentini et al. } \\
\text { 2014). [34] }\end{array}$ \\
\hline $\begin{array}{l}\text { High shear stress generated on the } \\
\text { membrane surface by moving the } \\
\text { membranes or the continuous phase } \\
\text { (Katoh et al. 1996). [33] }\end{array}$ & $\begin{array}{l}\text { High shear stress and low dispersed } \\
\text { phase flux to obtain droplets } \\
\text { detachment from the pore before that } \\
\text { droplets coalescence } \\
\text { [Piacentini, 2016] [35] }\end{array}$ & \\
\hline $\begin{array}{l}\text { Low dispersed phase flux. Particle } \\
\text { size proportionally increases as a } \\
\text { function of the dispersed phase flux } \\
\text { increase [Piacentini, 2016] [35] }\end{array}$ & & \\
\hline $\begin{array}{l}\text { Decreasing the interfacial tension } \\
\text { between the dispersed and continuous } \\
\text { phase. Emulsifiers that quickly } \\
\text { adsorb to the newly formed interface } \\
\text { allow the production of particles with } \\
\text { smaller size (Schröder et al. 1998) } \\
\text { [36] }\end{array}$ & & \\
\hline
\end{tabular}

\section{PHARMACEUTICAL PARTICLE DESIGN}

\section{Development of micro-/nano-carriers with different structures}

Emulsion droplets produced by membrane emulsification are used for the production of different micro-/nano-carriers by integration with various secondary reactions [19 Vladisavljevic, 2015].

In the present review, pharmaceutical particle fabrication by integration of membrane emulsification and various secondary reactions is described (Table 2).

$\mathrm{O} / \mathrm{W}$ and W/O emulsions produced by membrane emulsification have been used to produce pharmaceutical micro-/nano particles with tuned structure such as gel microbeads, solid lipid particles, micro/nanospheres, liquid-core/polymer-shell particles, polymer core/polymer-shell, complex coacervates and colloidosomes (Figure 5 and 6, Table 2). Biodegradable materials such as Poly(lactic-co-glycolic acid) (PLGA), Polycaprolactone (PCL), Sodium Alginate, Chitosan, poly(Llactide) (PLLA), Eudragit, etc are employed. The nature of the drug to encapsulate (hydrophilic or hydrophobic) and the 
target application, including organ delivery, administration route, stimulus responsive properties, controlled release, determine the selection of the wall material.

\section{Production of micro-/nano-carriers from o/w emulsions}

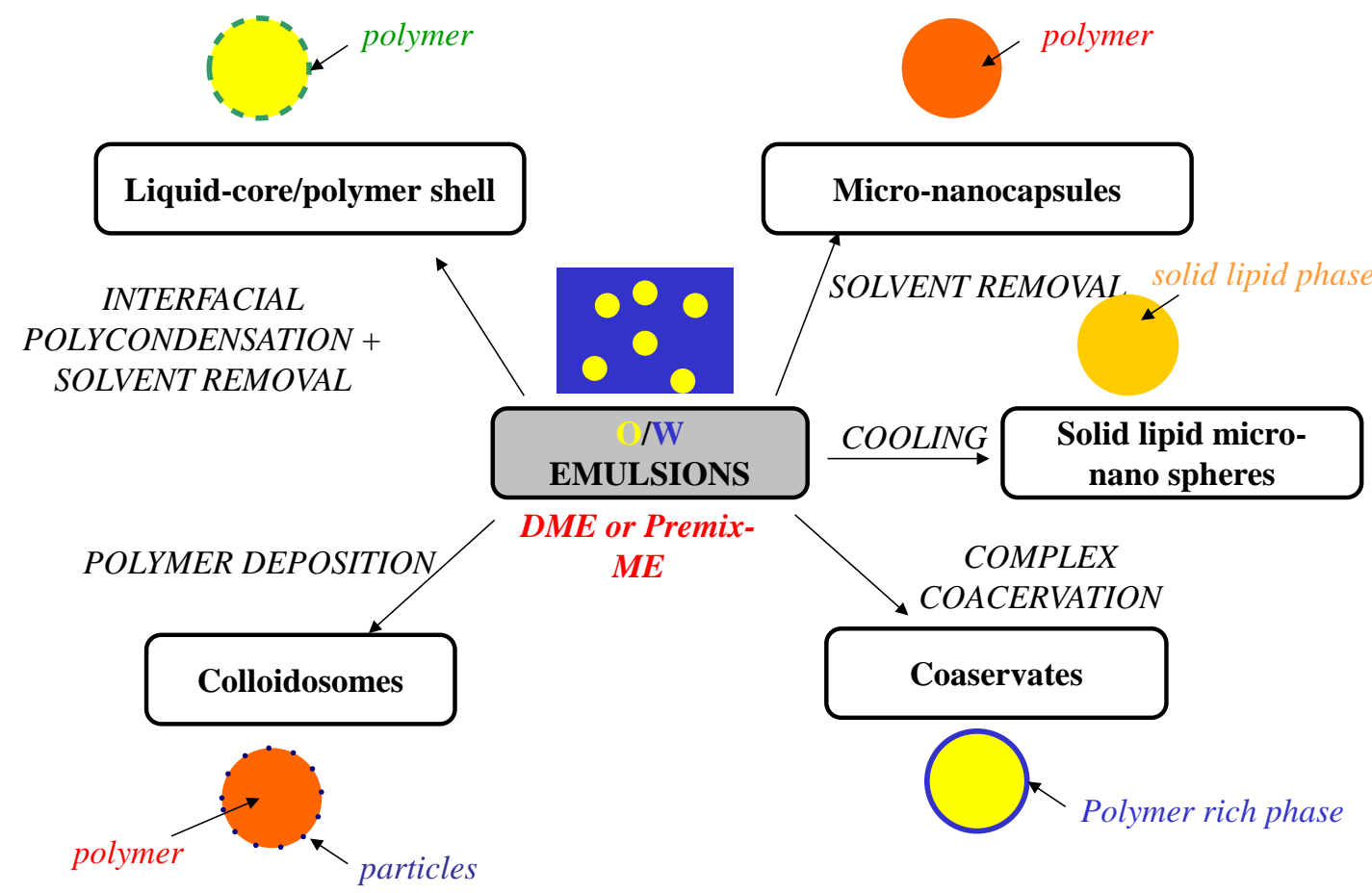

Figure 5. Micro-/nano-carriers production starting from o/w emulsions by integrating membrane emulsification with various secondary reactions.

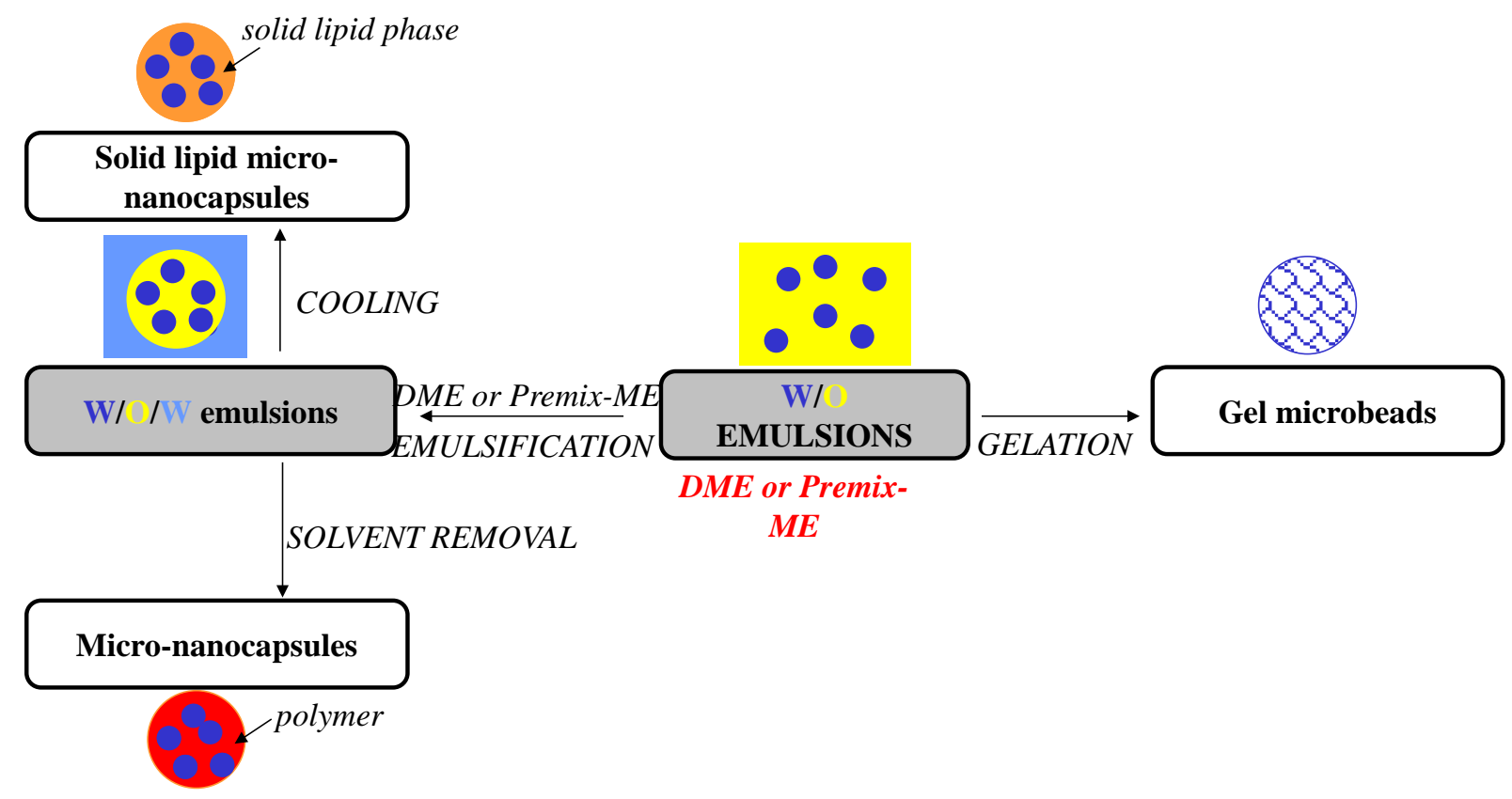

Production of micro-/nano-carriers from w/o emulsions

Figure 6. Micro-/nano-carriers production starting w/o emulsions by integrating membrane emulsification with various secondary reactions.

Gel microbeads are spherical hydrogel microparticles produced by injecting an aqueous solution containing the polymer through the membrane pores followed by cross-linking reaction. The cross-linking reaction can be carried out by: 
- Internal gelation. The polymer (i.e. Na-alginate) and the crosslinking agent in non-dissociated form (i.e. $\mathrm{CaCO}_{3}$ ) are suspended in the dispersed phase [38, 39 Liu, 2003, Hanga, 2014]. After emulsion production, a species (i.e. $\mathrm{H}^{+}$) is added in the continuous phase in order to diffuse into the droplets and activate the crosslinking agent forming the solid beads.

- External gelation. The polymer (i.e. Na-alginate, Chitosan) is dissolved in the dispersed phase and the crosslinking agent ( $\mathrm{Ca}^{++}$, glutaraldehyde, tripolyphospate) is added after emulsion production, forming the solid beads [40- 46 You, 2001; Wang, 2005; Akamatsu, 2010; Lv, 2009; Ma, 2010; Lai, 2015].

- Gel formation by cooling. The emulsification is carried out at a temperature higher than the temperature to coilto helix transition of the polymer (gelatine, agarose) [47-49 Zhou, 2007; 2008; 2009]. Gel beads are obtained by cooling the resultant $\mathrm{W} / \mathrm{O}$ emulsion.

- Gel formation by droplet merging. Two W/O emulsions are mixed: one containing droplets of the polymer solution (i.e. Na-alginate) and the other containing droplets of the cross-linking agent $\left(\mathrm{CaCl}_{2}\right)[42,50 \mathrm{Akamatsu}$, 2010; Nan, 2014]. Gel beads are produced by droplets merging.

- Gel formation by heating. A W/O emulsion containing the polymer (quaternized chitosan, proteins) is heated at the gelation temperature of the polymer promoting chain interaction otherwise not possible at room temperature [51, $52 \mathrm{Wu}, 2008$; Surh, 2005].

Solid lipid particles are particles formed from lipids that are solid at room temperature (i.e. saturated fatty acids, esters of glycerol and Polyethylene glycol (PEG)) [53, 54 Kukizaki, 2007; Laouini, 2014]. O/W, W/O/W and S/O/W emulsions are produced at the above the melting point followed by cooling the emulsion below the melting point.

Micro/nanospheres are matrix type particles (entire mass is solid) while micro/nanocapsules are vescicular system in which a liquid core is surrounded by a polymeric membrane. Micro/nanospheres and micro/nanocapsules are produced from $\mathrm{O} / \mathrm{W}$ and $\mathrm{W} / \mathrm{O} / \mathrm{W}$ or $\mathrm{S} / \mathrm{O} / \mathrm{W}$ emulsions containing a hydrophobic polymer (i.e. PLA, PLGA, PELA, PCL) dissolved in the oil phase, respectively [55- 60 Imbrogno, 2014; Ito, 2011; Doan, 2011; Ito, 2004; Zhang, 2015] . Solvent removal from the oil phase allows obtaining the solidified particles.

Liquid-core/polymer-shell particles are produced from $\mathrm{O} / \mathrm{W}$ emulsions in which the oil phase contains a hydrophobic polymer, a volatile water-immiscible good solvent for the polymer and non-volatile water-immiscible non-solvent [61, 62 Sawalha, 2008; Wagdare, 2011]. Solvent removal causes the formation of the solid shell because of polymer precipitation.

Polymer core/polymer-shell capsules are produced combining solvent evaporation with interfacial polymerization starting from $\mathrm{O} / \mathrm{W}$ emulsion. The dispersed phase contains polymer and a hydrophobic monomer, while the continuous phase contains a hydrophilic monomer [63 Chu, 2002]. After solvent evaporation, the new formed polymer formed a polymer shell around the other polymer. Alternatively, the dispersed phase contains the hydrophobic monomer while the hydrophilic monomer is added in the continuous phase and the polycondensation precedes at the surface of the organic droplets.

Complex coacervates can be formed by mixing a polyanionic polymer (i.e. polysaccaraide) with a polycationic polymer (i.e. protein from animal and vegetal source). Polymers with opposite charges stick together and form soluble and insoluble complexes, depending on solutions concentration and $\mathrm{pH}$, which are deposited around oil droplets forming a shell [64 Piacentini, 2013].

Colloidosomes are microcapsules that consist of a hollow core coated by a shell composed of self assembled colloidal particles and they are produced from a Pickering emulsion (a particles stabilized emulsion) after polymer deposition [65 Nan, 2014].

Representative figures of particles produced by membrane emulsification process are reported in Figure 7. 


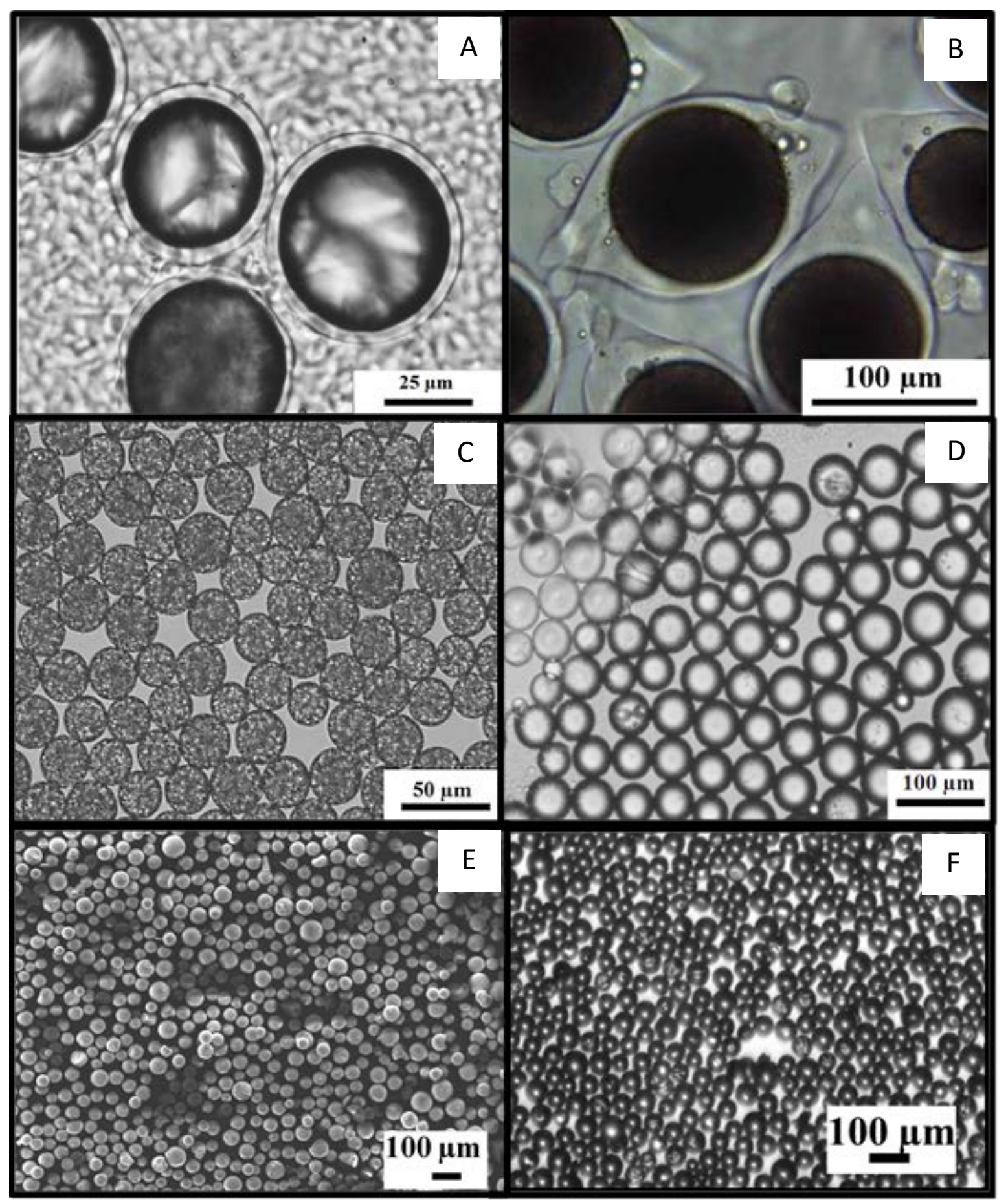

Figure 7. Particles produced by membrane emulsification coupled with; A-B) complex coacervation (core-shell particles); C-D) solvent diffusion (biodegradable polymer particles) and D-E) drying (inorganic particles). 
Table 2. Examples of structured particles for application in pharmaceutical field fabricated by integration of membrane emulsification and secondary reaction

\begin{tabular}{|c|c|c|c|}
\hline Particles & Secondary reaction & Wall Material & References \\
\hline \multirow[t]{5}{*}{ Gel microbeads } & $\begin{array}{l}\text { Internal gelation from } \mathrm{W} / \mathrm{O} \\
\text { emulsion }\end{array}$ & Sodium Alginate & $\begin{array}{l}\text { 38, } 39 \\
\text { Liu, } 2003 \\
\text { Hanga, } 2014\end{array}$ \\
\hline & $\begin{array}{l}\text { External gelation from } \mathrm{W} / \mathrm{O} \\
\text { emulsion }\end{array}$ & $\begin{array}{l}\text { Sodium Alginate } \\
\text { Chitosan } \\
\text { Haemoglobin }\end{array}$ & $\begin{array}{l}42-46 \\
\text { You, 2001 } \\
\text { Wang, 2005 } \\
\text { Akamatsu, } 2010 \\
\text { Lv, 2009 } \\
\text { Ma, } 2010 \\
\text { Lai, } 2015\end{array}$ \\
\hline & $\begin{array}{l}\text { Gel formation by cooling from } \\
\text { W/O emulsion }\end{array}$ & Agarose & $\begin{array}{l}\text { 47-49 } \\
\text { Zhou, 2007; } \\
\text { 2008; } 2009\end{array}$ \\
\hline & $\begin{array}{l}\text { Gel formation by droplet merging } \\
\text { from W/O emulsion }\end{array}$ & $\begin{array}{l}\text { Chitosan } \\
\text { Alginate }\end{array}$ & $\begin{array}{l}42,50 \\
\text { Akamatsu, } 2010 \\
\text { Nan, } 2014\end{array}$ \\
\hline & $\begin{array}{l}\text { Gel formation by heating from } \\
\text { W/O emulsion }\end{array}$ & $\begin{array}{l}\text { Chitosan } \\
\text { Whey protein isolate }\end{array}$ & $\begin{array}{l}\text { 51, } 52 \\
\text { Wu, } 2008 \\
\text { Surh, } 2005\end{array}$ \\
\hline Solid lipid particles & $\begin{array}{l}\text { Melt solidification from } \mathrm{W} / \mathrm{O} \text {, } \\
\mathrm{O} / \mathrm{W}, \mathrm{S} / \mathrm{O} / \mathrm{W} \text { emulsion }\end{array}$ & $\begin{array}{l}\text { Tripalmitin } \\
\text { Glyceryl palmitostearate }\end{array}$ & $\begin{array}{l}\text { 53, } 54 \\
\text { Kukizaki, } 2007 \\
\text { Laouini, } 2014\end{array}$ \\
\hline Micro/nanospheres & $\begin{array}{l}\text { Solvent removal from } \mathrm{O} / \mathrm{W} \\
\text { emulsion }\end{array}$ & $\begin{array}{l}\text { PCL } \\
\text { PLGA } \\
\text { PLA }\end{array}$ & $\begin{array}{l}\text { 55-60 } \\
\text { Imbrogno, } 2014 \\
\text { Ito, } 2011 \\
\text { Doan, } 2011 \\
\text { Ito, } 2004 \\
\text { Zhang, } 2015\end{array}$ \\
\hline $\begin{array}{l}\text { Liquid-core/polymer- } \\
\text { shell capsules }\end{array}$ & $\begin{array}{l}\text { Solvent removal from } \mathrm{O} / \mathrm{W} \\
\text { emulsion }\end{array}$ & $\begin{array}{l}\text { PLLA } \\
\text { Eudragit }\end{array}$ & $\begin{array}{l}61,62 \\
\text { Sawalha, } 2008 \\
\text { Wagdare, } 2011\end{array}$ \\
\hline $\begin{array}{l}\text { Polymer core/polymer- } \\
\text { shell capsules }\end{array}$ & $\begin{array}{l}\text { Interfacial polymerization/Solvent } \\
\text { removal from } \mathrm{O} / \mathrm{W} \text { emulsion }\end{array}$ & $\begin{array}{l}\text { poly(d, l-lactide-co-glycolide)/ } \\
\text { poly(ethyl 2-cyanoacrylate) }\end{array}$ & $\begin{array}{l}23 \\
\text { Lee, } 2010\end{array}$ \\
\hline Micro/nanocapsules & $\begin{array}{l}\text { Solvent removal from } \mathrm{W} / \mathrm{O} / \mathrm{W} \text { or } \\
\mathrm{S} / \mathrm{O} / \mathrm{W} \text { emulsion }\end{array}$ & PLGA & $\begin{array}{l}58,66-69 \\
\text { Doan, } 2011 \\
\text { Ma T, 2014 A } \\
\text { Ma T, } 2014 \text { B } \\
\text { Ma T, } 2014 \text { C } \\
\text { Wang, } 2013\end{array}$ \\
\hline Porous particles & Interfacial polycondensation & $\begin{array}{l}\text { poly(N-isopropylacrylamide) } \\
\text { (PNIPAM) }\end{array}$ & 63 Chu, 2002 \\
\hline Complex Coacervates & Complex coacervation & Gelatin-Gum Arabic & $\begin{array}{l}64 \text { Piacentini, } \\
2013\end{array}$ \\
\hline Colloidosomes & Interfacial particle self-assembly & Alginate-Chitosan & 65 Nan, 2014 \\
\hline
\end{tabular}

\section{Targeting of particles}

Recent years have witnessed increasing attention to stimulus responsive drug carrier polymers because their properties can be tailored to fit the requirements required for drug delivery. Triggering mechanisms for micro-nanoparticles release include biological, chemical, photo, thermal, electrical, and magnetic stimuli. The combination of stimuli-responsive materials and membrane emulsification method allows designing particles with tailored smart and responsive properties for pharmaceutical applications. In this paragraph, such examples the design of stimulus responsive carriers by membrane emulsification process will be highlighted.

Thermoresponsive microparticles have been obtained by coating the alginate beads produced by membrane emulsification with Poly-N-isopropylacrylamide (pNIPAM) [39 M. P. Hanga, 2014]. The amino groups from the amine terminated pNIPAM form polyelectrolyte complexes with carboxylic acid groups in the alginate network. Temperature induced 
transition of the amine-terminated pNIPAM in aqueous solution has been demonstrated to be a function of the pH. The protonation of amino groups of the amine-terminated pNIPAM modified the intra-molecular electrostatic forces by modifying the temperature-induced collapse of the modified polymer chains. Thermoresponsive microcapsules suitable for drug delivery systems have been developed by using a porous membrane and a linear-grafted poly(Nisopropylacrylamide) (PNIPAM) chains in the membrane pores acting as thermoresponsive gates [63 Chu, 2002]. The preparation was carried out by using membrane emulsification and interfacial polymerization to prepare the core-shell microcapsules. The "on/off" of vitamin B12 due to the closed/open state of the grafted "gates" was achieved.

$\mathrm{pH}$ responsiveness has been produced polysaccharide particles prepared by membrane emulsification method [70, 71 Zhang, 2011; Lv, 2011]. By using dual cross-linking by $\mathrm{Ca}^{2+}$ ions and chitosan, alginate particles were prepared by membrane emulsification to carry insulin for oral delivery [70 Zhang, 2011]. The alginate-chitosan microspheres were found to be promising carrier for oral administration of protein or peptide drugs by in vitro and in vivo tests demonstrating targeted drug delivery at intestinal level. BY using quaternized chitosan, the intestinal permeability of chitosan nanoparticles containing paclitaxel nanocrystals were improved [71 Lv, 2011]. Pickering emulsions with pH responsive properties have been produced by premix membrane emulsification using chitosan-coated alginate particles as emulsifiers [65 F. Nan et al., 2014]. The emulsions were $\mathrm{pH}$ dependent owing to the assembled pH-sensitive particles, and they can be stable at $4.6<\mathrm{pH}<9$. Uniform-sized $\mathrm{pH}$-sensitive quaternized chitosan microspheres were prepared by combining SPG membrane emulsification technique and a thermal-gelation method. The obtained microsphere dissolved rapidly in acid solution ( $\mathrm{pH}$ 5) and kept stable in neutral solution ( $\mathrm{pH} 7.4$ ) influencing the drug release behavior. Bovine serum albumin (BSA) used as a model drug was rapidly released in acid solution and slowly in neutral medium [52 Wu, 2008]. Ultrasound-assisted drug delivery is an emerging technique that has the advantage of being non-invasive, efficiently and specifically targeted and controllable [72 Sirsi SR, 2014]. Ultrasound contrast agents in the form of gas-filled microbubbles can be injected intravenously and can be applied to target drug delivery and enhancement of drug action. In a preliminary study, Pan et l., [73] (J. Pan, 2008) demonstrated the use of SPG membrane emulsification technique and ultrasound method to prepare ultrasound contrast agents based on a high molecular polymer-poly lactic acid (PLA) and loaded with Hydroxycamptothecin (HCPT) for cancer treatment.

The presence of biomolecules specific to disease state or an organ may be useful to regulate the release of drugs. A multiple emulsion containing a bio-receptor (Con A) that specifically recognizes and interacts with an artificial ligand (Glucose) was manufactured by the membrane process and used as a model system [64 Piacentini 2011]. Membrane emulsification has been used in the W/O and W/O/W emulsion preparation. Con A was adsorbed at emulsion droplet interface and the presence of additional molecules (such as other emulsifiers) contributed to emulsion stability. The progressive addition of glucose promoted the drug release, confirming the stimulus responsive property of the multiple emulsion. The system takes advantage from the mild operative conditions used for emulsion preparation preserving the biofunctionl properties of Con A. The model system studied has a potential use as insulin controlled delivering systems for diabetes treatment.

Lipid nanoparticles for target organ delivery were designed by covalent conjugating, on the surface, a M-cell selective molecular signature, ulex europaeus agglutinin-1 (UEA-1), and a toll-like receptor (TLR)-agonist adjuvant monophosphoryl lipid (AMPL) to intimately interact with the mucosal mucosal dendritic cells [68 T. Ma, 2014]. The functionalization with UEA-1 allowed the almost exclusive adhesion to M-cells, leading to specific absorption and continuous retention in the target organ (gut) while the TLR-agonist MPL played a crucial role in up-regulating the phagocytosis of mucosal dendritic cells.

\section{Administration routes}

Various routes of administration play a marked role in the bioavailability of the active drug for treatment of various diseases and disorders. An accurate control of particle size is especially required for parenteral administration (which includes intravenous, intramuscular, subcutaneous route as well as some specialized route i.e. intra-arterial). The size of particles must be significantly smaller than $5 \mu \mathrm{m}$ in order to prevent embolism for intravenous applications. The preparation of micro and nano polycaprolactone particles in a size range between $2.35 \mu \mathrm{m}$ and 210 nm was successfully achieved by using pulsed back-and-forward membrane emulsification [55 Imbrogno, 2014].Aqueous colloidal drug carrier dispersions based on nonpolar lipids for intravenous administration were produced by direct and premix SPG membrane emulsification method [74 S. Joseph, 2014]. Mean particle size below $500 \mathrm{~nm}$ and a particle size distribution completely in the nanometer range were only obtained using the membrane with the smallest pore size $(0.1 \mu \mathrm{m})$ by the direct method. Instead, premix emulsification worked much better for the preparation of particles in the lower nanometer range with very short preparation time and reduced stress to the dispersion than the direct preparation method. An effective and safe formulation for the sustained-release of recombinant human growth hormone (rhGH) has been produced using poly(monomethoxypolyethylene glycol-co-d,l-lactide) (mPEG-PLA, PELA) microspheres [75 Y. Wei, 2012]. In vivo, subcutaneous administration test demonstrated that PELA microspheres have the potential to be clinically effective and safe when administered only once every two months, a dose regime for better patient acceptance and compliance. PELA microspheres produced by membrane emulsification have a potential to be used to reduce the frequency of medication as prolonged drug delivery device. Uniformly sized microparticles of poly(d,l-lactic-co-glycolic) (PLGA) acid, with controllable median diameters within the size range 40-140 micrometres, for subcutaneous controlled drug release were successfully prepared by membrane emulsification followed by solvent removal [76 G. Gasparini, 2008]. 
Subcapsular renal injection is a novel administration method for local delivery of therapeutics for the treatment of kidney related diseases. Poly(D,L-lactic-co-hydroxymethyl glycolic acid) (PLHMGA) microspheres loaded with near-infrared dye-labeled bovine serum albumin (NIR-BSA) were prepared by premix membrane emulsification [77 F. Kazazi-Hyseni, 2015]. The produced microspheres provided a continuous release at the site of administration over a period of 3 weeks. Additionally, they demonstrated the potential to reduce side effects of therapeutic proteins by increasing the fluorescent signal at the site of injection and decreasing it elsewhere in the body.

The oral route remains the preferred route of administration to ensure patient satisfaction and compliance. However, the poor stability within the gastrointestinal tract or the poor solubility in gastrointestinal fluids, the low mucosal permeability, and/or the extensive first-pass metabolism can determine a low drug bioavailability after oral administration. Drug/carrier particulate systems are an attractive drug delivery strategy for highly potent drug substances normally unsuitable for oral use. By combining size control and size uniformity, achieved by membrane emulsification, with surface functionalization, by embedding the surface of nanoparticles (NPs) with one layer of phospholipids, T. Ma et al. reported the preparation of PLGA-lipid NPs as a promising oral vaccine delivery system [66 T. Ma, 2014]. A solid emulsion of itraconazole with increased solubility, release rate and oral bioavailability has been produced by combining SPG membrane emulsification with spray drying [78 Y-K Choi, 2012].Drug topical administration is used to have a local target rather than systemic. However, many topically administered drugs have systemic effects, because they reach the circulation after being absorbed by the surrounding tissue. Topical medications are applied directly to the skin or mucous membranes (i.e. nasal, rectal, vaginal). Few examples are reported in literature on the use of membrane emulsification for the production of particles for inhalation therapy [79 Bao D.,]. For inhalation administration, required for both local and systemic drug delivery, aerosols with a size (aerodynamic diameter) ranging from 0.5 to $5 \mu \mathrm{m}$ demonstrated efficient delivery to the lung while aerosols with a size of $2 \mu \mathrm{m}$ around are capable of targeting the deep lung, i.e. alveolar region. Membrane emulsification has been successfully applied in the production of rifampicin-loaded PLGA microparticles for the inalation therapy of tuberculosis [59, 80-82 Makino K, 2004; Ito, 2004, 2008, 2009]. Considering the strict restriction on the use of pharmaceutical excipients for inhalation therapy, engineered inhalable pure drug (i.e. carrier-free) particles in the form of nanoparticle agglomerates or relatively large porous drug particles $(>5 \mu \mathrm{m})$ are currently under investigations. Membrane emulsification can support the research in this area to produce an efficient inhalation delivery system with superior aerosolisation and targeting capability.

As far as we are aware, no specific formulation for dermal application has been developed by membrane emulsification. However, the application of this technology offers new possibilities to produce finished dermal products with enhanced skin feel, creaminess, flow and other aspects of these products, which depend upon the droplet size and size distribution.

\section{Improved Drug-loading efficiency / encapsulation efficiency}

In the development of drug delivery systems, both drug-loading efficiency (DLE) and encapsulation efficiency (EE) have to be considered. The DLE is the ability of the material to entrap the drug and suitable particles for drug delivery should have high DLE in order to minimize administration and number of doses. On the other end, the EE describes the efficiency of the preparation method to incorporate the drug into the carrier system. For that reason, the DLE is an important parameter of the drug delivery systems influencing the rate and extent of drug release while the EE can be used to compare the efficiency of various processes used to incorporate the drug in a carrier.

Membrane emulsification provides highly efficient encapsulation because each droplet is formed individually, at low imposed shear and pressure. In a few papers, the EE obtained by using membrane emulsification and conventional mechanical stirring methods is compared [83-85 R. Liu, 2006; M. Matos, 2015; S. Ramakrishnan, 2013]. The EE was increased from $32.85 \%$ to $81.28 \%$ when membrane emulsification was used instead of the stirring method in the production of insulin-loaded PLA/PLGA microcapsules starting from W/O/W emulsions [83 R. Liu, 2006]. EE was considerably higher when membrane emulsification was applied in the second emulsification step, resulting in an increase of $24.7 \%$ and $8 \%$ for double emulsions containing resveratrol and vitamin B12, respectively [84 M. Matos, 2015]. When the rotor-stator was used, the encapsulation efficiency of fish oil was 17 or $22 \%$ for whey protein isolate (WPI) and whey protein hydrolysate (WPH), respectively, while when ME was used the values increased to $29 \%$ and 34-36 \% for WPI and WPH, respectively [85 S. Ramakrishnan, 2013].

The effect of process parameters and chemical parameters during premix membrane emulsification on EE and DLE has been also investigated [86 Y. Yu, 2013]. After the preemulsion passed though the membrane more than three times, EE and DLE decreased from $81.8 \pm 4.5$ and $48.4 \% \pm 3.3 \%$ for three cycles to $71.8 \pm 7.7$ and $20.7 \% \pm 6.1 \%$, for five cycles, respectively. EE and DLE decreased when high transmembrane pressure was used because preemulsion droplets break caused by the strong shear force generated. EE and DLE increased, with the increase of the stability of the molecular layer of surfactant in the oil-water interface (i.e. PVA) and as a function of amphipathic property of the polymer (PLATPGS respect to PLGA).

A.K. Pawlik and I.T.Norton [87 A.K. Pawlik, I.T.Norton, 2012] studied the effect on the encapsulation- efficiency of three different techniques: high-shear mixer, cross-flow membrane and rotating membrane for the secondary emulsification step in the production of duplex W1/O/W2 emulsions. It was shown that due to vigorous processing inside the cross-flow membrane module, emulsions prepared with this technique had similar encapsulation efficiency to emulsions prepared with a high-shear mixer while a rotating membrane demonstrated higher encapsulation efficiency. 
Process and formulation parameters, which accelerate the solidification of the particles, will improve the EE of amphiphilic and hydrophilic drugs:

- Polymer parameters: polymer concentration, molecular weight, composition, polymer solubility in the solvent. Encapsulation efficiency increases with increasing polymer concentration and molecular weight as a result of the increased viscosity and faster solidification.

- Drug parameters: solubility of drug in the external phase, partition coefficient, drug-polymer interactions. The drug solubility into the external phase is important because it determines the maximum amount that can be dissolved in the external phase during the post-emulsification steps. Many drugs have some solubility in both water and oil phases, which may impact their physical and chemical stability. The partition of the drug between oil and water phases depends on solute type, solvent type, and environmental conditions, such as $\mathrm{pH}$, ionic strength, dielectric constant, and temperature. In addition, the interaction between drug and polymer contributes to increasing encapsulation efficiency.

- Solvent parameters: solvent-non solvent relative solubility, ratio of solvent to non-solvent, the emulsifier. Selection of solvent system is based on solubility of polymer and type of solidification method of preparation used. The 'high' solubility of solvent into the non solvent allowed relatively fast mass-transfer between the dispersed and the continuous phases and led to fast precipitation of the polymer increasing the encapsulation efficiency. The volume of the non-solvent provides a high concentration gradient of the solvent across the phase boundary by diluting the solvent, leading to fast solidification of the particles. The emulsifier in the continuous phase or used during the post-emulsification treatment also can influence the encapsulation efficiency because contributes to improve emulsion stability. However, the emulsifier can also increase the solubility of drugs in the continuous phase.

Figure 7 illustrates the important factors that contribute to the encapsulation efficiency.

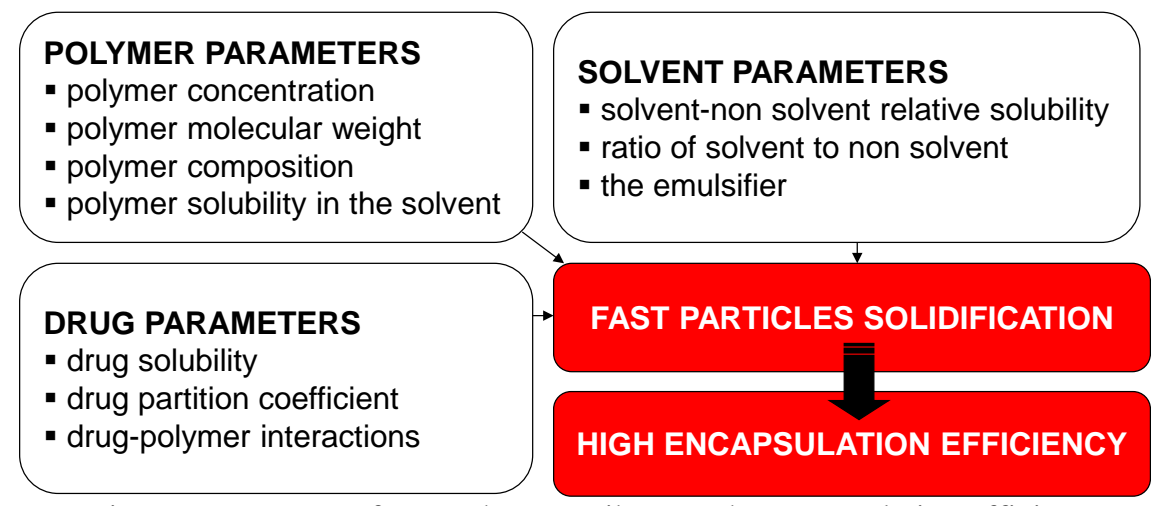

Figure 7. Important factors that contribute to the encapsulation efficiency

The effect of several parameters that play a role in particle solidification, and consequently in drug encapsulation efficiency, has been studied in combination with the membrane emulsification process.

In cases in which double emulsions have been used for the preparation of drug delivery systems such for vaccine delivery or protein delivery, the loss of proteins/peptides is mainly due to the water channels between the internal and external phase allowing the soluble biomolecules to diffuse through concentration gradient. The presence of a lipid layer structure has been demonstrated to make the Lipid NPs more efficient in protein loading [66 T. Ma, 2014] probably because the lipid molecules prevented protein diffusion during the formation of the pre-emulsion and during the evaporation of the solvent in the secondary step of solidification. R. Liu et al. demonstrated that the drug encapsulation efficiency was affected by the emulsion stability (correlated with PLA/PLGA ratio, $\mathrm{NaCl}$ concentration in outer water phase, inner water phase volume), $\mathrm{pH}$-value in outer water phase (by modifying the solubility of the drug in the outer water phase) and the size of microcapsules (by modifying the specific surface between the emulsion droplets and the outer water phase became larger) [83 R. Liu, 2006]. Higher EE of PLGA colloidosomes was obtained in respect to the PLGA microcapsules (96.7\% and $71.2 \%$, respectively) [65 Nan, 2014]. This was a result of the high stability of the Pickering emulsion due to the irreversible adsorption of the particles (chitosan-coated alginate particles) at the interface, which offers an improved loading efficiency for insulin. Moreover, the particle-composed shell can act as a physical barrier preventing the leak of insulin from the internal water phase to the external water phase.

Han et al. 2015 showed that the EE and the DLE of HCPT changed according to the weight ratio of chitosan and drug (when at 5:1 and 20:1, the entrapment efficiency were $75.2 \%$ and $90.4 \%$, and the drug loading of drug were $12.4 \%$ and $4.2 \%$ ), leading to either higher entrapment efficiency with lower drug loading or higher drug loading with lower entrapment efficiency and drug wasted [98 Han et al. 2015]. W. Wei et al found that the EE was reduced when a derivative $\mathrm{N}$-[(2-hydroxy-3-trimethylammonium) propyl] chitosan chloride (HTCC) with a high degree of substitution was employed, because the presence of quaternized groups excludes the cross-linking reaction and thus leads to fewer crosslinked microspheres in the emulsion. However, steric hindrance by quaternized groups would also reduce leakage of 
insulin from the microspheres during the cross-linking reaction and a higher DLE could be achieved [90 W. Wei, 2010]. Piacentini et al. showed that the EE is a function of the partition coefficient of the drug in the two phases that are used for emulsion preparation [35 Piacentini 2016]. The encapsulation efficiency for catechol and biophenols was $98 \% \pm 1 \%$ and $92 \% \pm 3 \%$, that correspond to a partition coefficient between oil and water phase of 0.02 and 0.09 , respectively.

\section{APPLICATIONS}

The most recent works on the use of membrane emulsification for the preparation of pharmaceutical particles are summarized in this section and they are described considering their final target application (Table 3). 


\begin{tabular}{|c|c|c|c|c|c|}
\hline $\begin{array}{c}\text { Type of } \\
\text { particles }\end{array}$ & $\begin{array}{c}\text { Membrane } \\
\text { emulsification (ME) } \\
\text { process } \\
\end{array}$ & $\begin{array}{c}\text { Therapeutic } \\
\text { agent }\end{array}$ & Application & $\begin{array}{l}\text { Particle size } \\
\text { Particle size distribution } \\
\text { Encapsulation efficiency }\end{array}$ & $\begin{array}{c}\text { Referenc } \\
\text { e }\end{array}$ \\
\hline $\begin{array}{l}\mathrm{W} / \mathrm{O} / \mathrm{W} \\
\text { emulsions }\end{array}$ & Direct ME & Doxorubicin & Cancer therapy & $\begin{array}{l}\mathrm{Dz}=0.440 \pm 0.007 \mu \mathrm{m} \\
\mathrm{PDI}=0.220 \pm 0.087 \\
\mathrm{EE} \% \sim 100 \%\end{array}$ & $\begin{array}{l}93 \\
\text { R. } \\
\text { Pradhan, } \\
2014\end{array}$ \\
\hline $\begin{array}{l}\mathrm{W} / \mathrm{O} / \mathrm{W} \\
\text { emulsions }\end{array}$ & Direct ME & $\begin{array}{l}\text { Epirubicin } \\
\text { hydrochlorid } \\
\text { e }\end{array}$ & Cancer therapy & $\begin{array}{l}\mathrm{Dm}=30 \pm 0.71 \mu \mathrm{m} \\
\delta=0.47 \pm 0.17 \\
\mathrm{EE} \%=\mathrm{NA}\end{array}$ & $\begin{array}{l}94 \\
\text { S. } \\
\text { Higashi, } \\
1995\end{array}$ \\
\hline $\begin{array}{l}\text { Chitosan } \\
\text { nanospheres }\end{array}$ & $\begin{array}{l}\text { Direct ME combined } \\
\text { with cross-linking }\end{array}$ & $\begin{array}{l}\text { Hydroxycam } \\
\text { ptothecin }\end{array}$ & Cancer therapy & $\begin{array}{l}\mathrm{Dm}=200-300 \mathrm{~nm} \\
\mathrm{PDI}=0.03 \\
\mathrm{EE} \%=90.4 \%\end{array}$ & $\begin{array}{l}88 \\
\text { Han, } 2015\end{array}$ \\
\hline $\begin{array}{l}\text { Chitosan } \\
\text { nanospheres }\end{array}$ & $\begin{array}{l}\text { Direct ME combined } \\
\text { with cross-linking }\end{array}$ & Paclitaxel & Cancer therapy & $\begin{array}{l}\mathrm{Dm}=130.27 \pm 6.73 \\
\mathrm{PDI}=0.034 \\
\mathrm{EE} \%=83.12 \pm 4.89\end{array}$ & $\begin{array}{l}71 \\
\text { Lv, } 2011\end{array}$ \\
\hline $\begin{array}{l}\text { PLA-TPGS } \\
\text { nanoparticles }\end{array}$ & $\begin{array}{l}\text { Pre-mix ME } \\
\text { combined with } \\
\text { solvent } \\
\text { diffusion/evaporation }\end{array}$ & Docetaxel & Cancer therapy & $\begin{array}{l}\mathrm{Dm}=306.8 \pm 5.5 \mathrm{~nm} \\
\mathrm{PDI}=0.098 \pm 0.064 \\
\mathrm{EE} \%=81.8 \pm 4.5 \%\end{array}$ & $\begin{array}{l}86 \\
Y . Y u \\
2013\end{array}$ \\
\hline $\begin{array}{l}\text { Lipid-PLGA } \\
\text { nanoparticles }\end{array}$ & $\begin{array}{l}\text { Direct ME combined } \\
\text { with double } \\
\text { emulsion-solvent } \\
\text { evaporation method }\end{array}$ & Ovalbumin & - & $\begin{array}{l}\mathrm{Dm}=215.3 \pm 3.5 \mathrm{~nm} \\
\mathrm{PDI}=0.048 \pm 0.018 \\
\mathrm{EE} \%=95.3 \pm 4.8 \%\end{array}$ & $\begin{array}{l}66 \\
\text { T. Ma, } \\
2014\end{array}$ \\
\hline $\begin{array}{l}\text { PLA/PLGA } \\
\text { microcapsules }\end{array}$ & $\begin{array}{l}\text { Directed ME } \\
\text { combined with } \\
\text { double emulsion- } \\
\text { evaporation method }\end{array}$ & Insulin & Diabetes & $\begin{array}{l}\mathrm{Dm}=9 \mu \mathrm{m} \\
\mathrm{PDI}=\mathrm{NA} \\
\mathrm{EE} \%=81.28 \%\end{array}$ & $\begin{array}{l}83 \\
\text { R. Liu, } \\
2006\end{array}$ \\
\hline $\begin{array}{l}\text { PELA } \\
\text { microspheres }\end{array}$ & $\begin{array}{l}\text { Premix ME } \\
\text { combined with } \\
\text { emulsion-solvent } \\
\text { extraction }\end{array}$ & $\begin{array}{l}\text { recombinant } \\
\text { hepatitis B } \\
\text { surface } \\
\text { antigen }\end{array}$ & Vaccine & $\begin{array}{l}\mathrm{Dm}=1.13 \pm 0.03 \mu \mathrm{m} \\
\mathrm{CV}=18.9 \% \\
\mathrm{EE} \%=90.4 \pm 4.3 \%\end{array}$ & $\begin{array}{l}99 \\
\text { Q. Wei, } \\
2008\end{array}$ \\
\hline $\begin{array}{l}\text { PLA } \\
\text { microparicles }\end{array}$ & $\begin{array}{l}\text { Premix ME } \\
\text { combined with } \\
\text { emulsion-solvent } \\
\text { extraction }\end{array}$ & $\begin{array}{l}\text { H5N1 } \\
\text { influenza } \\
\text { split vaccine }\end{array}$ & Vaccine & $\mathrm{Dm}=820 \mathrm{~nm}$ & $\begin{array}{l}\text { 60 Zhang, } \\
2014\end{array}$ \\
\hline $\begin{array}{l}\text { Chitosan } \\
\text { micropartilces }\end{array}$ & $\begin{array}{l}\text { Premix ME and } \\
\text { layer-by-layer (LbL) } \\
\text { technology }\end{array}$ & $\begin{array}{l}\text { anthrax } \\
\text { protective } \\
\text { antigen } \\
\end{array}$ & Vaccine & $\mathrm{Dm}=1002.1 \pm 16.9 \mu \mathrm{m}$ & $\begin{array}{l}103 \text { Liu, } \\
2013\end{array}$ \\
\hline $\begin{array}{l}\text { PLA } \\
\text { Microspheres }\end{array}$ & $\begin{array}{l}\text { Premix ME } \\
\text { combined with } \\
\text { emulsion-solvent } \\
\text { extraction }\end{array}$ & $\begin{array}{l}\text { hepatitis B } \\
\text { surface } \\
\text { antigen }\end{array}$ & Vaccine & $\mathrm{Dm}=800 \mathrm{~nm}$ & $\begin{array}{l}104 \text { Chen, } \\
2104\end{array}$ \\
\hline $\begin{array}{l}\text { PLA } \\
\text { Microspheres }\end{array}$ & $\begin{array}{l}\text { Premix ME } \\
\text { combined with } \\
\text { emulsion-solvent } \\
\text { extraction }\end{array}$ & $\begin{array}{l}\text { hepatitis B } \\
\text { surface } \\
\text { antigen }\end{array}$ & Vaccine & $\begin{array}{l}\mathrm{Dm}=900 \mathrm{~nm} \text { PDI }= \\
0.0029\end{array}$ & $\begin{array}{l}106 \text { Liu, } \\
2014\end{array}$ \\
\hline $\begin{array}{l}\text { PELA } \\
\text { microspheres }\end{array}$ & $\begin{array}{l}\text { Premix ME } \\
\text { combined with } \\
\text { emulsion-solvent } \\
\text { extraction }\end{array}$ & $\begin{array}{l}\text { recombinant } \\
\text { human } \\
\text { growth } \\
\text { hormone } \\
\text { (rhGH) } \\
\end{array}$ & $\begin{array}{c}\text { Growth } \\
\text { hormone } \\
\text { deficiency }\end{array}$ & $\begin{array}{l}\mathrm{Dm}=2.07 \mu \mathrm{m} \\
\mathrm{PDI}=0.708 \\
\mathrm{EE} \%=89.3 \%\end{array}$ & $\begin{array}{l}109 \mathrm{Yi} \\
\text { Wei, } 2011\end{array}$ \\
\hline $\begin{array}{l}\text { Chitosan } \\
\text { microspheres }\end{array}$ & $\begin{array}{l}\text { Directed ME } \\
\text { combined with }\end{array}$ & Insulin & Diabetes & $\begin{array}{l}\mathrm{Dm}=7.7 \mu \mathrm{m} \\
\mathrm{CV}=10.9 \%\end{array}$ & $\begin{array}{l}100 \mathrm{~W} . \\
\text { Wei, } 2010\end{array}$ \\
\hline
\end{tabular}




\begin{tabular}{|c|c|c|c|c|c|}
\hline & $\begin{array}{l}\text { glutaraldehyde cross- } \\
\text { linking method }\end{array}$ & & & $\mathrm{EE} \%=63.5 \%$ & \\
\hline $\begin{array}{l}\text { Multiple } \\
\text { S/O/W } \\
\text { emulsion }\end{array}$ & $\begin{array}{l}\text { premix-SPG } \\
\text { membrane } \\
\text { emulsification }\end{array}$ & insulin & Diabetes & $\mathrm{Dm}=1 \mu \mathrm{m}$ & $\begin{array}{l}\text { 101Tooris } \\
\text { aka, } 2003\end{array}$ \\
\hline $\begin{array}{l}\text { Nanoemulsion } \\
\mathrm{s}\end{array}$ & $\begin{array}{l}\text { ME combined spray- } \\
\text { drying technique }\end{array}$ & Flurbiprofen & $\begin{array}{l}\text { Treatment of } \\
\text { pain and } \\
\text { inflammation } \\
\text { caused by } \\
\text { arthritis }\end{array}$ & $\begin{array}{l}\mathrm{Dm}=70 \mathrm{~nm} \\
\mathrm{PDI}=\mathrm{NA} \\
\mathrm{EE} \%=\mathrm{NA}\end{array}$ & $\begin{array}{l}89 \mathrm{Oh}, \\
2013\end{array}$ \\
\hline O/W emulsion & $\begin{array}{l}\text { ME combined spray- } \\
\text { drying technique }\end{array}$ & Silymarin & $\begin{array}{l}\text { Antioxidant, } \\
\text { and anti-cancer } \\
\text { activity, liver } \\
\text { protection } \\
\end{array}$ & $\begin{array}{l}\mathrm{Dm}=214.3 \pm 1.9 \mathrm{~nm} \\
\mathrm{PDI}=0.342 \pm 0.001 \\
\mathrm{EE} \%=\mathrm{NA}\end{array}$ & $\begin{array}{l}90 \text { Yang } \\
\text { KY, } 2013\end{array}$ \\
\hline $\begin{array}{l}\text { PLGA } \\
\text { microspheres } \\
\text { containing } \\
\end{array}$ & $\begin{array}{l}\text { ME combined with } \\
\text { solvent evaporation } \\
\text { method }\end{array}$ & rifampicin & $\begin{array}{l}\text { Tubercle } \\
\text { treatment }\end{array}$ & $\begin{array}{l}\mathrm{Dm}=4.31 \mu \mathrm{m} \\
\mathrm{CV}=17.4 \% \\
\mathrm{LE} \%=62.6 \%\end{array}$ & $\begin{array}{l}59 \mathrm{~F} . \text { Ito, } \\
2008\end{array}$ \\
\hline $\begin{array}{l}\text { Chitosan } \\
\text { nanoparticles }\end{array}$ & $\begin{array}{l}\text { ME combined with } \\
\text { cross-linking method }\end{array}$ & Tacrine & Alzheimer & $\begin{array}{l}\text { Dz }=90 \mathrm{~nm} \\
\mathrm{PDI}=0.22 \\
\mathrm{EE} \%=65 \%\end{array}$ & $\begin{array}{l}91 \mathrm{~S} . \\
\text { Hassani, } \\
2015 \\
\end{array}$ \\
\hline $\begin{array}{l}\text { Solid lipid } \\
\text { microcapsules }\end{array}$ & $\begin{array}{l}\text { ME combined with } \\
\text { cross-linking method }\end{array}$ & Vitamin B12 & $\begin{array}{l}\text { dietary } \\
\text { supplement and } \\
\text { to treat certain } \\
\text { anemias } \\
\end{array}$ & $\begin{array}{l}\mathrm{Dm}=17.50 \mu \mathrm{m} \\
\mathrm{PDI}=0.4 \\
\mathrm{EE} \%=94.6 \%\end{array}$ & $\begin{array}{l}53 \mathrm{M} . \\
\text { Kukizaki, } \\
2007\end{array}$ \\
\hline $\begin{array}{l}\text { Solid } \\
\text { nanoemulsion }\end{array}$ & $\begin{array}{l}\text { ME with spray } \\
\text { drying technique }\end{array}$ & Itraconazole & Mycosis & $\begin{array}{l}\mathrm{Dz}=400-600 \mathrm{~nm} \\
\mathrm{PDI}=0.15-0.4\end{array}$ & $\begin{array}{l}78 \text { Choi, } \\
2012\end{array}$ \\
\hline $\begin{array}{l}\text { pNIPAM } \\
\text { microcarriers }\end{array}$ & $\begin{array}{l}\text { ME combined with } \\
\text { internal gelation }\end{array}$ & - & cell attachment & $\begin{array}{l}\mathrm{Dm}=98 \mu \mathrm{m} \\
\mathrm{PDI}=0.19\end{array}$ & $\begin{array}{l}39 \text { M. P. } \\
\text { Hanga, } \\
2014\end{array}$ \\
\hline $\begin{array}{l}\mathrm{bHb} / \mathrm{BSA} \\
\text { microspheres }\end{array}$ & $\begin{array}{l}\text { ME combined with } \\
\text { cross-linking method }\end{array}$ & - & oxygen carriers & $\begin{array}{l}\mathrm{Dm}=3.9 \mu \mathrm{m} \\
\mathrm{CV}=11 \%\end{array}$ & $\begin{array}{l}46 \text { Y. Lai, } \\
2015\end{array}$ \\
\hline $\begin{array}{l}\text { PLLA } \\
\text { microcapsules }\end{array}$ & $\begin{array}{l}\text { premix ME and } \\
\text { double emulsion } \\
\text { method }\end{array}$ & - & $\begin{array}{l}\text { ultrasound } \\
\text { imaging }\end{array}$ & $\begin{array}{l}\mathrm{Dm}=1-2 \mu \mathrm{m} \\
\mathrm{CV}=11 \%\end{array}$ & $\begin{array}{l}106 \text { B. } \\
\text { Liu, } 2014\end{array}$ \\
\hline $\begin{array}{l}\text { PEG-PLGA } \\
\text { microcapsules }\end{array}$ & $\begin{array}{l}\text { premix ME and } \\
\text { double emulsion } \\
\text { method }\end{array}$ & - & $\begin{array}{l}\text { ultrasound/mag } \\
\text { netic resonance } \\
\text { bimodal } \\
\text { imaging }\end{array}$ & $\begin{array}{l}\mathrm{Dm} \sim 3.7 \mu \mathrm{m} \\
\mathrm{PDI}=0.03\end{array}$ & $\begin{array}{l}107 \text { S. Xu, } \\
2015\end{array}$ \\
\hline
\end{tabular}

Bioactives drug delivery systems: Lipophilic and Hydrophilic drugs encapsulation

Micro and nanoparticles containing bioactive materials with a uniform size have a great potential as carriers in drug delivery systems, since the release rate and loading efficiency of drug can be constant in each particle. Lipophilic drug delivery systems are designed to address improved solubility and bioavailability.

Flurbiprofen-loaded nanoparticles have been prepared with polyvinylpyrrolidone (PVP) using SPG membranes and a spray-drying technique [89 Oh, 2013]. The drug concentration-time curve from the nanoparticles was about 10-fold greater compared to the commercially available product demonstrating an improved bioavailability of a poorly watersoluble flurbiprofen. Silymarin (a flavonoid complex with antioxidant, liver protection and anti-cancer activity)-loaded nanoemulsion was formulated using SPG membrane emulsification technique and spray-dried to obtain solid state nanoparticles [90 Yang KY, 2013]. In particular, the area under the concentration-time curve of Silymarin-loaded nanoparticles was approximately 1.3-fold greater than that of the commercial product. In addition, the silymarin-loaded nanoparticles demonstrated improved hepatoprotective effects compared with silymarin powder and the commercial product. Solid nanoemulsion containing itraconazole and dextran as solid carrier were produced by combining membrane emulsification and spray drying [78 Choi, 2012]. The solid emulsion after oral administration demonstrates greatly improved oral bioavailability of the drug in rats.

Monodisperse PLGA microspheres containing rifampicin (RFP), anti-tubercle drug, were prepared by membrane emulsification combined with the solvent evaporation method [81 F. Ito, 2008].

Hydrophilic drugs include macromolecules, such as protein and peptides, and small drugs. Protein drug delivery systems will be described in the next paragraph. There are currently many examples of applications of membrane emulsification for small hydrophilic drugs. Anti-Alzheimer's drug, Tacrine, in chitosan NPs was encapsulated with an EE of around $65 \%$ by membrane emulsification combined with cross-linking [91 S. Hassani, 2015]. Solid lipid microcapsules (SLMCs) 
with a narrow droplet diameter distribution and encapsulating vitamin B12 were prepared by a two-step membrane emulsification technique at a temperature higher than the melting point of the oil phase [53 M. Kukizaki, 2007]. A maximum EE of vitamin B12 of 97.7\% was achieved and no leakage of vitamin B12 from the uniformly sized SLMCs was observed at body temperature. Monodisperse Ca-alginate microspheres were prepared using the membrane emulsification method to encapsulate three ionic types of drugs (Sodium salicylate (anionic), Lidocaine (cationic) and 4acetamidophenol (non-ionic)) [40 You JO, 2001]. Lidocaine (cationic drug) release was more retarded than that of the anionic drug, because of the electrostatic attraction between the negative charge of the ionized carboxyl group in the alginate chain and the positive charge of the cationic drug. In an acidic release medium, a slow release was observed due to the low swelling characteristic and the increased viscosity of alginate, regardless of ionic type of drug.

\section{Anticancer drug delivery systems}

Anticancer drug delivery through smart, targeted micro and nanoparticles offers many attractive features, including: 1) improved delivery of lipophilic drugs; 2) targeted delivery of drugs in a cell- or tissue specific manner in order to improve treatment efficacy while minimize systemic side effects; 3) better protection of the drugs in the systemic circulation before they can reach the targets (e.g., the highly acidic environment in the stomach or the lysosomes of a cell, and the high levels of proteases or other enzymes in the blood stream); 4) controlled release as a function of target stimuli; and 5) codelivery of multiple types of drugs and/or diagnostic agents (e.g., contrast agents) for combination therapy and real-time readout on the treatment efficacy [92 110 T. Sun, 2014]. The application of membrane emulsification technology is demonstrated to promote progress in the therapy of cancer by assessing some of the aforementioned goals.

Doxorubicin (DOX)-loaded W/O/W microemulsions were produced by Shirasu Porous Glass (SPG) membrane using W/O emulsions prepared by homogenization as feed emulsions [93 R. Pradhan, 2014]. The SPG membrane emulsification technique has been demonstrated as a promising technique for anticancer drug delivery. Indeed, the formulations showed a sustained release profile, prolonged the plasma drug concentration after intravenous aDministration to rats and gave about 17-fold higher area under the drug concentration-time curve (AUC) compared to free DOX solution.

Porous quaternized chitosan nanoparticles containing paclitaxel nanocrystals prepared by membrane emulsification demonstrated improved therapeutic efficacy in non-small-cell lung cancer after oral administration [71 Lv, 2011 ]. Chitosan nanoparticles prepared by premix SPG membrane emulsification technique demonstrated a potential use as a sustained release system for hydroxycamptothecin encapsulation in liver cancer treatment as well as for other anti-cancer drugs [88 J. Han, 2015].

Table 3. Particles produced by membrane emulsification explored as carriers for drug delivery (Dz: Z average; Dm: Median Particle Diameter; PDI: polydispersity index; $\delta$ : dispersion coefficient; NA: not available)

The production at pilot scale of Docetaxel (DTX)-loaded poly(lactide)-d- $\alpha$-tocopheryl polyethylene glycol 1000 succinate (PLA-TPGS) nanoparticles have been successfully achieved by using (SPG) premix membrane-emulsification technique [86 Y. Yu, 2013]. The tumor-inhibitory effect of the nanoparticles was studied in vivo in an H22 tumor-bearing mice model via intravenous administration. PLA-TPGS nanoparticles demonstrated superior pharmacokinetic and anticancer effects compared to the commercially available Taxotere.

W/o/w emulsions have been prepared to transport and deliver anticancer drugs for hepatocellular carcinoma [94, 95 Higashi, 1995, 2000]. The emulsion containing Iodinated Poppy-Seed Oil (IPSO) and Epirubicin hydrochloride was directly administered into the hepatic artery. Microdroplets accumulated only in hepatocellular carcinoma tissue and remained in the tissue for more than 3 weeks affecting tumour cells. The clinical tests showed a cancer volume decreased to a quarter of its initial size.

\section{Protein drug delivery systems}

Protein and peptide drugs have a number of potential applications as therapeutic agents instead of conventional chemical drugs such as low side effect, specific targeting site, low dosage, and so forth. However, protein and peptide drugs are generally characterized by a short biological half-life time, because they are easily hydrolysed or degraded by enzymes in vivo. Microencapsulation techniques have been developed to maintain serum drug concentration at a higher constant value for a prolonged time or to change injection formulation to orally or mucosally administered formulation.

A big challenge in protein drug delivery systems design is that the protein/peptide easily loses their bioactivity during preparation, storage, and release as a result of the shear force applied during emulsion preparation or protein unfolding /protein aggregation in the presence of an oil phase, oil/water interface, or hydrophobic surface [23 G. Ma, 2014]. The mild operative conditions of membrane emulsification technique can overcome the high shear force in conventional preparation method while opportune strategies have been developed for maintaining bioactivity of the encapsulated protein/peptide drugs. In particular, many strategies have been adopted to decrease the contact of protein molecules and hydrophobic interfaces: i) adding protection additives [96 F.T. Meng, 2004], ii) dispersing drug powder in oil phase [85 R. Liu, 2006], iii) designing amphiphilic block polymer PLA-PEG [96,75 F.T. Meng, 2004; Y. Wei, 2012], iv) optimizing 
the solidification step [51, 96-98 F.T. Meng, 2004; J. Wu, 2006; L.Y. Wang, 2006; J. Wu, 2008], v) modifying the particle morphologies [99 W.Wei, 2008].

Uniform-sized biodegradable PLA/PLGA microcapsules loaded with recombinant human insulin (rhI) were successfully prepared by combining a Shirasu Porous Glass (SPG) membrane emulsification and a double emulsion-evaporation method [83 R. Liu, 2006]. Membrane emulsification provided tuning the size of microcapsules, adjusting the drug cumulative release profile by changing the size of microcapsules. Moreover, much higher encapsulation efficiency (91.82\%) can be obtained when compared with the conventional mechanical stirring method.

Colloidosomes have attracted significant attention as potential vehicles for the controlled delivery of active ingredients because their properties such permeability, mechanical strength, and environmental-sensitivity, can be easily tuned by selecting different particles as stabilizers. Uniform-sized Pickering emulsion stabilized with chitosan-coated alginate particles were prepared by premix membrane and used to produce colloidosomes as oral insulin delivery vehicles by the polymer deposition method [65 Nan, 2014]. The colloidosomes achieved a high EE of 97.6\% and a pH sensitive drug release (slow in simulated gastric fluid and rapid in simulated intestinal fluid). Furthermore, animal testing confirmed the strong hypoglycemic effects of insulin-loaded colloidosomes even up to $6 \mathrm{~h}$, suggesting colloidosomes as efficient oral insulin delivery vehicles.

The delivery of insulin by non-parenteral routes has gained significant attention over the last two decades. Hollow quaternized chitosan microspheres prepared by membrane emulsification and glutaraldehyde cross-linking have been developed as oral delivery of insulin [100 W. Wei, 2010]. Data demonstrated that microspheres were able to maintain the bioactivity of the encapsulated insulin, achieving bioadhesion of microspheres, increasing the loading ability and optimizing the release profile. In vivo tests demonstrated also an optimal reduction in blood glucose level and powerful therapeutic effects after oral administration of the designed microspheres. Multiple S/O/W emulsion for oral administration of insulin was produced by Toorisaka et al. [101 Toorisaka, 2003] with premix-SPG membrane emulsification. The monodisperse insulin multiple emulsions showed hypoglycemic activity for a long period after oral administration to rats. The authors indicated that the $\mathrm{S} / \mathrm{O} / \mathrm{W}$ emulsions with transforming insulin into a lipophilic complex and uniform droplets had good potential in the treatment of diabetes

\section{Vaccine delivery}

Application of particles prepared by membrane emulsification technique as the adjuvants of vaccine has attracted great attention in recent years, and has become an important new application field [21, 22Wang, 2015; Ma, G. (2014).]. Particles as vaccine adjuvants are used to protect the bioactivity of biomolecules, prolong their release profiles similar as the drug delivery system and to increase antigen uptake by antigen-presenting cells followed by facilitating the induction of potent immune responses. Membrane emulsification technology has been successfully applied in the design of particles as vaccine adjuvant. The size influence on immunity was eliminated due to uniform-sized microparticles with narrow size distributions obtained by membrane emulsifications. This helps in the understanding of the relevance of formulation parameters like materials, surface property of particle or the presence of surface active groups on the quality and quantity of immune response. Polymeric lipid NPs composed of a hydrophobic polymeric poly(D,L-lactide-co-glycolide) (PLGA) core and a surface coating of lipid monolayer as promising oral vaccine delivery system were produced by membrane emulsification and the double emulsion solvent evaporation method [67 T. Ma, 2014]. Compared with the pure PLGA NPs, the lipid NPs achieved higher DLE and EE for the encapsulated ovalbumin (OVA), used as a model vaccine. In vitro oral release studies showed the Lipid NPs were able to protect the loaded OVA from the harsh gastrointestinal environment for a long time. In addition, Lipid NPs showed higher affinity to the M-cells than PLGA NPs. Since the Mcells are crucial in particle translation as well as intimately associated with the underlying immune cells, the OVA-Lipid NPs effectively induced high level of IgG and IgA antibody responses. The ability of PLA-, PLGA-, and PELA based microparticles, produced by premix membrane emulsification, of inducing immune responses in vitro and in vivo has evaluated [102 Liu, 2013]. MP hydrophobicity has been demonstrated to be an important factor influencing the magnitude of immune responses induced by particulate used as vaccine adjuvants. Uniform-sized PLA microparicles were able to increase both humoral immune response and cell-mediated-immunity when used as adjuvants for H5N1 influenza split vaccine which might enhance crossprotection of influenza vaccine [61 Zhang, 2014]. Polycation surface modification also has been demonstrated to influence immune response. Higher surface charge of surface modified PLA microspheres produced by premix membrane emulsification led to increased antigen adsorption on MPs, promote antigen internalization into macrophages and activation, and facilitate phagocytic antigen localization independent of the lysosome, antibody and cytokine secretion [103, 104 Chen, 2014; Liu 2014]. Chitosan-based microparticles with abundant amino groups produced by premix-membrane emulsification contributed to complement activation and immune responses [105 Liu, 2013].

\section{Tissue engineering}

Membrane emulsification technology has many potential advantages for the manufacturing of cell delivery systems in non-denaturanting conditions and highly controlled production. Membrane emulsification is emerging as an effective technique for the production of particles in a size range of interest as scaffolds for various biopharmaceutical applications, 
including, microcarriers for cell culture by particle surface functionalization or by encapsulation. Membrane emulsification and internal gelation have been used at batch scale to produce uniform calcium alginate particles with controllable median diameters as microcarriers for cell attachment [39 M. P. Hanga, 2014]. The thermoresponsive properties of beads by amine terminated poly $\mathrm{N}$-isopropylacrylamide (pNIPAM) functionalization promoted cells detachment from the bead surface by simply lowering the temperature within the system to below the phase transition temperature. This study demonstrated the potential use of this technique for stem cell growth and recovery without the need for enzymatic based cell release.

An artificial oxygen carrier composed of bovine hemoglobin (bHb) and bovine serum albumin (BSA) were prepared by SPG membrane emulsification and their subsequent cross-linking by glutaraldehyde [46 Y. Lai, 2015]. The microspheres showed a narrow size distribution (the CV of the microsphere size was around 10\%) and good biocompatibility. The biomecules maintained their ability to bind and release oxygen. Because particle size ranged from 3.9 to $4.9 \mu \mathrm{m}$, bHbBSA microspheres are expected not to be uptaken by cells, they can be applied as oxygen carriers in cell culture in the future. Cytotoxicity tests in vitro demonstrated a relationship between the microsphere size and the cytotoxic effect [46 Y. Lai, 2015]. Microsphere diameter of $18.3 \mu \mathrm{m}$ showed good cellular compatibility regardless of the oxyhemoglobin percentage. Since cytotoxicity is a crucial factor in their applications, a systemic investigation would provide a new insight into the design of HBOCs.

\section{Biomedical imaging}

Gas-filled microcapsules have superior scattering properties compared with blood cells and the differences of compressibility and density between the microcapsules and the surrounding fluid make the microcapsules highly echogenic. The ultrasonic properties of the microcapsules are significantly dependent on their size and size distribution. B. Liu et al [106 B. Liu, 2014] adopted a premix membrane emulsification technique and double emulsion method to prepare uniform biodegradable polylactone microcapsules for enhancement of ultrasound intensity and duration. The effects of various process parameters on the size and size distribution for optimizing and scaling up the preparation of diverse uniform sized polylactone microcapsules. $4 \mu \mathrm{m}$ PLLA (poly(L-lactide)) microparticles prepared by using the optimized conditions were considerably stronger and longer than those of commercially available ultrasound contrast agents.

Enhanced multimodal imaging such as ultrasound imaging and magnetic resonance imaging have attracted great interests in recent years to achieve more abundant pathological information for accurately diagnosing complicated diseases. Premix membrane emulsification method was used to prepare uniform PEG-PLGA microcapsules with superparamagnetic $\mathrm{Fe}_{3} \mathrm{O}_{4}$ NPs embedded in the shell for ultrasound/magnetic resonance bimodal imaging [107 S. Xu, 2015]. The produced particles demonstrated improved stability in physiological solutions, simultaneously performance enhancement of ultrasound imaging and magnetic resonance imaging, no appreciable cytotoxicity and embolism to mice even at high dose.

NIR emitting CdSeTe/CdS/ZnS core/shell/shell quantum dot-encoded microbeads combined with common flow cytometry with one laser for multiplexed detection of HBV (hepatitis B virus) have been produced by membrane emulsification [108 Wang, X, 2013]. The particles have the potential to replace current multiple lasers based detection system.

\section{Conclusions}

Membrane emulsification is increasingly used for the production of single and multiple emulsions and solidified particles as carriers for drug delivery. The advantages of membrane emulsification in pharmaceutical particles production are in uniform and controlled particle size, mild operative conditions during droplet generation, increased encapsulation efficiency.

The wide range of strategies employed to control the shear at the membrane surface and to obtain high production rates with droplet size uniformities and target droplet to pore size ratio are a powerful tool for pharmaceutical industry to design particles with tuned properties.

The recent technical advancements in membrane emulsification technology, with particular reference to reliability and ability to scale production, are expected to promote the development of smart, targeted micro/nanoparticles as drug carriers significantly improving particles using sophisticated particle and process design in the pharmaceutical field. 


\section{References}

1 Piacentini E, Drioli E, Giorno L. Membrane emulsification technology: Twenty-five years of inventions and research through patent survey, J Membr Sci 2014; 468: 410-422.

2 Joscelyne SM, Trägårdh G, Membrane emulsification—a literature review, J. Membr. Sci. 2000, 169: 107-117

3 Charcosset C, Limayem I, Fessi H. The membrane emulsification process-a review. J. Chem. Technol. Biotechnol. 2004, 79: 209-218.

4 Dragosavac MM Membrane emulsification and filtration for engineered particles. Doctoral dissertation, (C) Marijana Dragosavac. 2011, Loughborough University

$5 \mathrm{Wu}$, J., Fan, Q., Xia, Y., \& Ma, G. (2015). Uniform-sized particles in biomedical field prepared by membrane emulsification technique. Chemical Engineering Science, 125, 85-97.

6 Liu, W., Yang, X., Ho, W.W.S. (2010). Preparation of uniform-sized multiple emulsions and micro/nano particulates for drug delivery by membrane emulsification. Journal of Pharmaceutical Sciences, 100, 75-93.

7 Huang HJ, Yuan WK, Chen XD. Microencapsulation based on emulsification for producing pharmaceutical products: a literature review. Developments in Chemical Engineering and Mineral Processing 2008, 14: 515-544.

8. Benita S (2006) Microencapsulation. Methods and Industrial Application, in New York, vol. 158, no. 8.

9 Karbstein H \& Schubert H Developments in the continuous mechanical production of oil-in-water macro-emulsions. Chemical Engineering Process 1995, 34: 205-211.

10 Nakashima T., Shimizu M., Kukizaki M., Particle control of emulsion by membrane emulsification and its application, Adv.DrugDeliv.Rev. 2000, 45: 47-56.

11 Limayem I., Charcosset C., Fessi H., The membrane emulsification process- a review, J. Chem. Biochem. Technol. 2004, 79: 209-218.

12 Gijsbertsen-Abrahamse A.J., van der Padt A., Boom R.M., Status of cross-flow membrane emulsification and outlook for industrial application, J. Membr. Sci. 2004, 230:149-159.

13 van der Graaf S., Schroën C.G.P.H., Boom R.M., Preparation of double emulsions by membrane emulsification- a review, J. Membr. Sci. 251 (2005) 7-15.

14 Charcosset C., Preparation of emulsions and particles by membrane emulsification for the food processing industry, J. Food Eng. 2009, 92: 241-249.

15 Nazir A., Schroën K., Boom R., Premix emulsification: a review, J. Membr. Sci. 362 (2010) 1-11.

16 Vladisavljević G.T., Kobayashi I., Nakajima M., Production of uniform droplets using membrane, microchannel and microfluidic emulsification devices, Microfluid. Nanofluid. (2012)151-178.

17 Spyropoulos F., Lloyd D.M., Hancocks R.D., Pawlik A.K., Advances in membrane emulsification. Part A: recent developments in processing aspects and micro- structural design approaches, J. Sci. Food Agric. 2014, 94: $613-627$.

18 Spyropoulos F., Lloyd D.M., Hancocks R.D., Pawlik A.K.,Advances in membrane emulsification. PartB: recent developments in modelling and scale-up approaches, J.Sci.FoodAgric.94(2014)628-638.

19 Vladisavljević G. T. Structured microparticles with tailored properties produced by membrane emulsification, Advances in Colloid and Interface Science 2015; 225: 53-87. 
20 Vladisavljević GT, Williams RA. Manufacture of large uniform droplets using rotating membrane emulsification. Journal of Colloid and Interface Science 2006; 299(1): 396-402.

21 Wang, L., Yang, T., \& Ma, G. (2015). Particle design of membrane emulsification for protein drug and vaccine delivery. Current pharmaceutical design, 21(19), 2563-2598.

22 Ma, G. (2014). Microencapsulation of protein drugs for drug delivery: strategy, preparation, and applications . Journal of Controlled Release 193, 324-340.

23 Lee J, Hwang DR, Shim SE. Controlling Morphology of Polymer Microspheres by Shirasu Porous Glass (SPG) Membrane Emulsification and Subsequent Polymerization: from Solid to Hollow, Macromolecular Research 2010; 18: 1142-1147.

24 Chu L, Xie R, Zhu J, Chen W, Yamaguchi T, Nakao S. Study of SPG membrane emulsification processes for the preparation of monodisperse core-shell microcapsules, Journal of Colloid and Interface Science 2003; 265: $187-196$.

25 Kukizaki M. Shirasu porous glass (SPG) membrane emulsification in the absence of shear flow at the membrane surface: influence of surfactant type and concentration, viscosities of dispersed and continuous phases, and transmembrane pressure. J Membr Sci 2009; 327: 234-243

26 Stillwell MT, Holdich RG, Kosvintsev SR, Gasparini G, Cumming IW. (2007). Stirred Cell Membrane Emulsification and Factors Influencing Dispersion Drop Size and Uniformity. Industrial \& Engineering Chemistry Research 2007; 46(3): 965-972.

27 Peng SJ, Fellow RAW. Controlled Production of Emulsions Using a Crossflow Membrane: Part II: Industrial Scale Manufacture. Chemical Engineering research and design 1998 ;76(8): 902-910.

28 Holdich RG, Dragosavac MM, Vladisavljevic GT, Piacentini E. Continuous Membrane Emulsification with Pulsed (Oscillatory ) Flow. Industrial \& Engineering Chemistry Research 2013, 52: 507-515.

29 Piacentini E, Drioli E, Giorno L. Pulsed back-and-forward cross-flow batch membrane emulsification with high productivity to obtain highly uniform and concentrate emulsions. Journal of Membrane Science 2014; 453: $119-125$.

30 Holdich RG, Dragosavac MM, Vladisavljevic GT. Membrane Emulsification with Oscillating and Stationary Membranes. Industrial \& Engineering Chemistry Research 2010, 49: 3810-3817.

31 Silva PS, Dragosavac MM, Vladisavljević GT, Bandulasena HCH, Holdich RG, Stillwell M, Williams B. (2015), Azimuthally oscillating membrane emulsification for controlled droplet production. AIChE J. 2015; 61: 3607-3615.

32 Suzuki K, Shuto I, Hagura Y, Characteristics of membrane emulsification method combined with preliminary emulsification for preparing corn oil-in- water emulsions. Food Sci.Technol.Int. 1996 2(1): 43-47.

33 Katoh R, Asano Y, Furuya A, Sotoyama K, Tomita M. Preparation of food emulsions using a membrane emulsification system. J Membr Sci 1996; 113: 131-135

34 Piacentini E, Imbrogno A, Drioli E, Giorno L. Membranes with tailored wettability properties for the generation of uniform emulsion droplets with high efficiency. J Membr Sci 2014; 459: 96-103

35 Piaecntini E, Poerio T, Bazzarelli F, Giorno L. Microencapsulation by membrane emulsification of biophenols recovered from olive mill wastewater, Membranes 2016; 6:1-11. doi:10.3390/membranes6020025.

36 Schröder V, Beherend O, Schubert H. Effect of dynamic interfacial tension on the emulsification process using microporous ceramic membranes. J Colloid Interface Sci 1998; 202: 334-340

37 Kobayashi I, Yasuno M, Iwamoto S, Shono A, Satoh K, Nakajima M. Microscopic observation of emulsion droplet formation from a polycarbonate membrane. Colloids Surf A Physicochem Eng Asp 2002: 207: 185-196 
38 Liu XD, Bao DC, Xue WM, Xiong Y, Yu WT, Yu XJ, Ma XJ, Yuan Q. Preparation of uniform calcium alginate gel beads by membrane emulsification coupled with internal gelation. J Appl Polym Sci 2003; 87: 848-852.

39 Hanga MP, Holdich RG. Membrane Emulsification for the production of uniform poly-N-isopropylacrylamide-coated alginate particles using internal gelation. Ind Eng Chem Res 2014; 92: 1664-1673.

40 You JO, Park SB, Park HY, Haam S, Chung CH, KimWS. Preparation of regular sized Ca-alginate microspheres using membrane emulsification method. J Microencapsul 2001; 18: 521-532.

41 Wang LY, Ma GH, Su ZG. Preparation of uniform sized chitosan microspheres by membrane emulsification technique and application as a carrier of protein drug. J Control Release 2005; 106 :62-75.

42 Akamatsu K, Kaneko D, Sugawara T, Kikuchi R, Nakao S. Three preparation methods for monodispersed chitosan microspheres using the Shirasu porous glass membrane emulsification technique and mechanisms of microsphere formation. Ind Eng Chem Res 2010; 49: 3236-3241.

43 Lv PP, Wei W, Gong FL, Zhang YL, Zhao HY, Lei JD, Wang LY, Ma GH. Preparation of uniformly sized chitosan nanospheres by a premix membrane emulsification technique. Ind Eng Chem Res 2009; 48: 8819-8828.

44 Ma GH, Yang J, Lv PP, Wang LY, Wei W, Tian R, Wu J, Su ZG. Preparation of uniform microspheres and microcapsules by modified emulsification process. Macromol Symp 2010; 288: 41-48.

45 Lai YT, Sato M, Ohta S, Akamatsu K, Nakao S, Sakai Y, Ito T. Preparation of uniformsized hemoglobin-albumin microspheres as oxygen carriers by Shirasu porous glass membrane emulsification technique. Colloids Surf B 2015; 127: $1-7$.

46 Lai YT, Sato M, Ohta S, Akamatsu K, Nakao S, Sakai Y, Ito T. Size-dependent interaction of cells and hemoglobinalbumin based oxygen carriers prepared using the SPG membrane emulsification technique. Biotechnol Progress 2015; 31: 1676-1684.

47 Zhou QZ, Wang LY, Ma GH, Su ZG. Preparation of uniform-sized agarose beads by microporous membrane emulsification technique. J Colloid Interface Sci 2007; 311: 118-27.

48 Zhou QZ, Wang LY, Ma GH, Su ZG. Multi-stage premix membrane emulsification for preparation of agarose microbeads with uniform size. J Membr Sci 2008; 322: 98-104.

49 Zhou QZ, Ma GH, Su ZG. Effect ofmembrane parameters on the size and uniformity in preparing agarose beads by premix membrane emulsification. J Membr Sci 2009; 326: 694-700.

50 Nan F, Wu J, Qi F, Liu Y, Ngai T, Ma G. Uniform chitosan-coated alginate particles as emulsifiers for preparation of stable Pickering emulsions with stimulus dependence. Colloids Surf A 2014; 456: 246-252.

51 Wu J, Wei W, Wang LY, Su ZG, Ma GH. Preparation of uniform-sized pH-sensitive quaternized chitosan microsphere by combining membrane emulsification technique and thermal-gelation method. Colloids Surf B 2008; 63:164-75.

52 Surh J, Vladisavljević GT, Mun S, McClements DJ. Preparation and characterization of water/oil and water/oil/water emulsions containing biopolymer-gelled water droplets. J Agric Food Chem 2007; 55:175-184.

53 Kukizaki M, Goto M. Preparation and evaluation of uniformly sized solid lipid microcapsules using membrane emulsification. Colloids Surf A 2007; 293: 87-94.

54 Laouini A, Charcosset C, Fessi H, Schroen K. Use of dynamic membranes for the preparation of vitamin E-loaded lipid particles: an alternative to prevent fouling observed in classical cross-flow emulsification. Chem Eng J 2014; 236: 498-505. 
55 Imbrogno A, Piacentini E, Drioli E, Giorno L. Micro and nano polycaprolactone particles preparation by pulsed backand-forward cross-flow batch membrane emulsification for parenteral aDministration. International Journal of Pharmaceutics 2014; 477: 344-350.

56 Imbrogno A, Piacentini E, Drioli E, Giorno L. Preparation of uniform plycaprolactone microparticles by membrane emulsification/solvent diffusion process. J Membr Sci 2014; 467: 262-268.

57 Ito F, Kanakubo Y, Murakami Y. Rapid preparation of monodisperse biodegradable polymer nanospheres using a membrane emulsification technique under low gas pressure. J Polym Res 2011; 18:2077-2085.

58 Doan TVP, Couet W, Olivier JC. Formulation and in vitro characterization of inhalable rifampicin-loaded PLGA microspheres for sustained lung delivery. Int J Pharm 2011; 414: 112-117.

59 Ito F, Makino K. Preparation and properties of monodispersed rifampicin-loaded poly(lactide-co-glycolide) microspheres. Colloids Surf B Biointerfaces. 2004 a;39(1-2):17-21. 11.

60 Zhang W, Wang L, Liu Y, Chen X, Li J, Yang T, et al. Comparison of PLA microparticles and alum as adjuvants for H5N1 influenza split vaccine: adjuvanticity evaluation and preliminary action mode analysis. Pharm Res 2014; 31: 10151031.

61 Sawalha H, Fan Y, Schroën K, Boom R. Preparation of hollow polylactide microcapsules through premix membrane emulsification—effects of nonsolvent properties. J Membr Sci 2008;325:665-71.

62 Wagdare NA, Marcelis ATM, Boom RM, van Rijn CJM. Porous microcapsule formation with microsieve emulsification. J Colloid Interface Sci 2011; 355: 453-457.

63 Chu LY, Park SH, Yamaguchi T, Nakao S. Preparation of micron-size monodispersed thermoresponsive core-shell microcapsules. Langmuir 2002; 18: 1856-1864.

64 Piacentini E, Drioli E, Giorno L. Preparation of Stimulus Responsive Multiple Emulsions by Membrane Emulsification Using Con A as Biochemical Sensor. Biotechnology and Bioengineering 2011; 10: 913-923.

65 Nan F, Wu J, Qi F, Fan Q, Ma G, Ngai T. Preparation of uniform-sized colloidosomes based on chitosan-coated alginate particles and its application for oral insulin delivery. J Mater Chem B 2014; 2: 7403-7409.

66 Ma T, Wang L, Yang T, Ma G, Wang S, Homogeneous PLGA-lipid nanoparticle as a promising oral vaccine delivery system for ovalbumin. Asian Journal of Pharmaceutical Sciences 2014; 9: 129-136.

67 Ma T, Wang L, Yang T, Wang D, Ma G, Wang S. PLGA-lipid liposphere as a promising platform for oral delivery of proteins. Colloids Surf B 2014; 117:512-519.

68 Ma T, Wang L, Yang T, Ma G,Wang S. M-cell targeted polymeric lipid nanoparticles containing a toll-like receptor agonist to boost oral immunity. Int J Pharm 2014; 473:296-303.

69 Wang G, Leng Y, Dou H,Wang L, LiW,Wang X, et al. Highly efficient preparation of multiscaled quantum dot barcodes for multiplexed hepatitis B detection. ASC Nano 2013; 7:471-481.

70 Zhang YL, Wei W., Lv PP, Wang LY, Ma GH. Preparation and evaluation of alginate-chitosan microspheres for oral delivery of insulin. Eur. Wei. Pharm. Biopharm. 2011; 77(1): 11-19.

61 Lv PP, Wei W, Yue H, Yang TY, Wang LY, Ma GH. Porous quaternized chitosan nanoparticles containing paclitaxel nanocrystals improved therapeutic efficacy in non-small-celllungcancerafteroralaDministration. Biomacromolecules 2011; 12(12): 4230-4239.

72 Sirsi SR, Borden MA, State-of-the-art materials for ultrasound-triggered drug delivery, Adv Drug Deliv Rev. 72 (2014) 3-14. 
73 Pan J, Hou Z, Zhu P, Wang Y, Wang Q, Zhang Q. Optimization of Production of PLA Microbubble Ultrasound Contrast Agents for Hydroxycamptothecin Delivery in BioMedical Engineering and Informatics, 2008. (BMEI 2008) International Conference on. Sanya, 27-30 May 2008 2008; 1: 400-406.

74 Joseph S, Bunjes H. Evaluation of Shirasu Porous Glass (SPG) membrane emulsification for the preparation of colloidal lipid drug carrier dispersions. European Journal of Pharmaceutics and Biopharmaceutics 2014; 87: $178-186$.

75 Wei Y, Wang YX, Kang AJ, Wang W, Ho S, Gao JF, Ma GH, Su ZG. A novel sustained-release formulation of recombinant human growth hormone and its pharmacokinetic, pharmacodynamic and safety profiles, Mol. Pharm. 2012; 9: 2039-2048.

76 G. Gasparini, S.R. Kosvintsev, M.T. Stillwell, R.G. Holdich, Preparation and characterization of PLGA particles for subcutaneous controlled drug release by membrane emulsification, Colloids and Surfaces B: Biointerfaces 61 (2008) 199207

77 Kazazi-Hyseni F, van Vuuren SH, van der Giezen DM, Pieters EH, Ramazani F, Rodriguez S, Veldhuis GJ, Goldschmeding R, van Nostrum CF, Hennink WE, Kok RJ, Release and pharmacokinetics of near-infrared labeled albumin from monodisperse poly(d,l-lactic-co-hydroxymethyl glycolic acid) microspheres after subcapsular renal injection. Acta Biomaterialia 2015; 22: 141-154.

78 Choi Y.K., Poudel B.K., Marasini N., Yang K.Y., Kim J.W., Kim J.O., Choi H., Yong C.S., Enhanced solubility and oral bioavailability of itraconazole by combining membrane emulsification and spray drying technique, International Journal of Pharmaceutics 2012, 434: 264-271

79 Bao D., Zhao, Y. Building Membrane Emulsification into Pulmonary Drug Delivery and Targeting, Pharmaceutical Research 2010, 27:2505-2508

80 Makino K, Nakajima T, Shikamura M, Ito F, Ando S, Kochi C, et al. Efficient intracellular delivery of rifampicin to alveolar macrophages using rifampicin-loaded PLGA microspheres: effects of molecular weight and composition of PLGA on release of rifampicin. Colloids Surf B Biointerfaces. 2004; 36(1):35-42. 10.

81 Ito F, Fujimora H, Honnami H, Kawakami H, Kanamura K, Makino K. Effect of polyethylene glycol on preparation of rifampicin-loaded PLGA microspheres with membrane emulsification technique. Colloids Surf B Biointerfaces. 2008;66(1):65-70. 12.

82 Ito F, Fujimori H, Honnami H, Kawakami H, Kanamura K, Makino K. Study of types and mixture ratio of organic solvent used to dissolve polymers for preparation of drug-containing PLGA microspheres. Eur Polym J. 2009;45(3):65867.

83 Liu R, Huang SS, Wan YH, Ma GH, Su ZG. Preparation of insulin-loaded PLA/ PLGA microcapsules by a novel membrane emulsification method and its release in vitro. Colloids Surf. B 2006; 51: 30-38.

84 M. Matos, G. Gutiérrez, O. Iglesias, J. Coca, C. Pazos, Enhancing encapsulation efficiency of food-grade double emulsions containing resveratrol or vitamin B12 by membrane emulsification, Journal of Food Engineering 2015, 166: 212-220

85 S. Ramakrishnan M.F., Aceña-Muñoz L., De Lamo-Castellví S., Güell C., Fish Oil Microcapsules from O/W Emulsions Produced by Premix Membrane Emulsification, Food Bioprocess Technol 6 (2013) 3088-3101

86 Yu Y, Tan S, Zhao S, Zhuang X., Song Q, Wang Y, Zhou Q, Zhang Z. Antitumor activity of docetaxel-loaded polymeric nanoparticles fabricated by Shirasu porous glass membrane-emulsification technique, International. Journal of Nanomedicine 2013; 8: 2641-2652.

87 Pawlik AK, Norton IT, Encapsulation stability of duplex emulsions prepared with SPG cross-flow membrane, SPG rotating membrane and rotor-stator techniques-A comparison. Journal of Membrane Science 2012; 415-416: 459-468.

88 Han J, Hou ZQ, Wang YG, Guo X. Synthesis and Evaluation of Hydroxycamptothecin encapsulated Chitosan Nanospheres for the Treatment of Liver Cancer. Technology in Cancer Research and Treatment 2015; 14: $111-117$. 
89 Oh D.H., Din F.U., Kim D.W., Kim J.O, Yong C.S., Choi H.G., Flurbiprofen-loaded nanoparticles prepared with polyvinylpyrrolidone using Shirasu porous glass membranes and a spray-drying technique: nano-sized formation and improved bioavailability. Journal of Microencapsulation 2013; 30: 674-680.

90 Yang K.Y., Hwang D.H., Yousaf A.M., Kim D.W, Shin Y.J., Bae O.N., Kim Y.I., Kim J.O., Yong C.S., Choi H.G. Silymarin-loaded solid nanoparticles provide excellent hepatic protection: physicochemical characterization and in vivo evaluation, Int J Nanomedicine. 2013; 8: 3333-3343.

91 Hassani S, Laouini A, Fessi H, Charcosset C. Preparation of chitosan-TPP nanoparticles using microengineered membranes - Effect of parameters and encapsulation of tacrine, Colloids and Surfaces A: Physicochemical and Engineering Aspects 2015; 482: 34-43.

92 Sun T, Zhang YS, Pang B, Hyun DC, Yang M, Xia Y. Engineered Nanoparticles for Drug Delivery in Cancer Therapy, Angew. Chem. Int. Ed. 2014; 53: 12320 - 12364

93 Pradhan R, Kim YI, Jeong JH, Choi HG, Yong CS, Kim JO. Fabrication, characterization and pharmacokinetic evaluation of doxorubicin-loaded water-in-oil-in-water microemulsions using a membrane emulsification technique. Chem Pharm Bull 2014;62(9): 875-882.Xu

94 Higashi S, Shimizu M, Nakashima T, Iwata K, Uchiyaemotherapyma F, Tateno S, Tamura S, Setoguchi T. Arterialinjection chemotherapy for hepatocellular carcinoma using monodispersed poppy-seed oil micro droplets containing fine aqueous vesicles of epirubicin. Cancer, 1995; 75: 1245-1254.

95 Higashi S, Setoguchi T. Hepatic arterial injection chemotherapy for hepatocellular carcinoma with epirubicin aqueous solution as numerous vesicles in iodinated poppy-seed oil microdroplets: clinical application of water-in-oil-in-water emulsion prepared using a membrane emulsification technique. Advanced Drug Delivery Reviews 2000; 45: 57-64.

96 Meng FT, Ma GH, Liu YD, Qiu W, Su ZG, Microencapsulation of bovine haemoglobin with high bio-activity and high entrapment efficiency using a w/o/w double emulsion technique. Colloids Surf. B 2004; 33: 177-183.

97 Wu J, Su ZG, Ma GH. A thermo- and pH-sensitive hydrogel composed of quaternized chitosan/glycerophosphate. Int. J. Pharm. 2006; 315: 1-11.

98 Wang LY, Gu YH, Su ZG, Ma GH. Preparation and improvement of release behaviour of chitosan microspheres containing insulin, Int. J. Pharm. 2006; 311: 187-195.

99 Wei W, Yuan L, Hu G, Wang LY, Wu J, Hu X, Su ZG, Ma GH. Monodisperse chitosan microspheres with interesting structures for protein drug delivery, Adv. Mater. 2008; 20: 2292-2296.

100 Wei W., Ma GH, Wang LY, Wu J, Su ZG. Hollow quaternized chitosan microspheres increase the therapeutic effect of orally administered insulin. Acta Biomaterialia 2010; 6 (1): 205-209.

101 Toorisaka E, Ono H, Arimori K, Kamiya N, Goto M. 2003. Hypoglycemic effect of surfactant-coated insulin solubilized in a novel solid-in-oil-in-water (S/O/W) emulsion. Int J Pharm 252:271-274

105 Liu Y, Yin Y, Wang LY, et al. Engineering biomaterial-associated complement activation to improve vaccine efficacy. Biomacromolecules 2013; 14: 3321-8.

104 Chen XM, Liu YY, Wang LY, et al. Enhanced humoral and cell mediated immune responses generated by cationic polymer-coated PLA microspheres with adsorbed HBsAg. Mol Pharm 2014; 11: 1772-84.

103 Liu YY, Chen XM, Wang LY, et al. Surface charge of PLA microparticles in regulation of antigen loading, macrophage phagocytosis and activation, and immune effects in vitro. Particuology 2014; 17: V-VII 
102 Liu Y, Yin Y, Wang LY, et al. Surface hydrophobicity of microparticles modulates adjuvanticity. J Mat Chem 2013; 1: 3888- 96.

106 Liu B, Zhou X, Yang F, Shen H, Wang S, Zhang B, Zhi G, Wu D. Fabrication of uniform sized polylactone microcapsules by premix membrane emulsification for ultrasound imaging. Polym. Chem. 2014; 5: 1693-1701.

107 Xu S, Yang F, Zhou X, Zhuang Y, Liu B, Mu Y, Wang X, Shen H, Zhi G, Wu D. Uniform PEGylated PLGA Microcapsules with Embedded Fe3O4 Nanoparticles for US/MR Dual-Modality Imaging, ACS Applied Materials \& Interfaces 2015; 7 (36): 20460-20468.

108 Wang X, Wang G, Li W, Zhao B, Xing B, Leng Y, Dou H, Sun K, Shen L, Yuan X, Li J, Sun K, Han J, Xiao H, Li Y, Huang P, Chen X. NIR-Emitting Quantum Dot-Encoded Microbeads through Membrane Emulsification for Multiplexed Immunoassays. Small 2013; 9: 3327-3335.

109 Wei Y., Y.X. Wang, W.Wang, S. Ho, W.Wei, G.H. Ma, mPEG-PLA microspheres with narrow size distribution increase the controlled release effect of recombinant human growth hormone, J. Mater. Chem. 21 (2011) 12691-12699. 